\title{
Petrology, geochemistry of hornblende gabbro and associated dolerite dyke of Paharpur, Puruliya, West Bengal: Implication for petrogenetic process and tectonic setting
}

\author{
Aditi Mandal, Arijit Ray*, Mayukhee Debnath and Sankar Prasad Paul \\ Presidency University, Kolkata 700 073, India. \\ ${ }^{*}$ Corresponding author. e-mail: rayarijit22@gmail.com
}

\begin{abstract}
Paharpur gabbroic intrusive is an arcuate body running east-west paralleling the foliation of Chhotanagpur Granite Gneiss which acts as country rock. The main gabbroic body is intruded by a number of dolerite dykes running north-south. It is composed of clinopyroxene $\left(\mathrm{Wo}_{48} \mathrm{En}_{40} \mathrm{Fs}_{12}-\mathrm{Wo}_{51} \mathrm{En}_{40} \mathrm{Fs}_{09}, \mathrm{mg}\right.$ no. 72-82), plagioclase $\left(\mathrm{An}_{52}-\mathrm{An}_{90}\right)$, hornblende (magnesian hornblende to ferro-tschermackite), orthopyroxene $\left(\mathrm{En}_{76}-\mathrm{En}_{79}\right)$ and ilmenite. Hornblende occurs as large poikilitic grain and constitutes around $60 \%$ of the rock. Both gabbro and associated dolerite dykes, show relatively primitive character (mg no. 6573). Primitive mantle-normalized and MORB-normalized spider diagrams indicate enrichment in Rb, $\mathrm{Ba}, \mathrm{Th}, \mathrm{La}, \mathrm{Sr}$ and depletion in Nb, Zr, Y, Ti and Nd. The LILE enrichment and Nb, Ti, Zr, Y depletion suggest arc like geochemical signature for the gabbroic and doleritic rocks of Paharpur. Flat to slightly LREE fractionated pattern and variable degree of REE enrichment is observed. An early stage fractionation of clinopyroxene, plagioclase, orthopyroxene, ilmenite and late stage reaction of cumulate pile and evolved melt/hydrous fluid is suggested for magmatic evolution of gabbro. Associated dolerite dykes, which are geochemically similar to the gabbro, have tholeiitic with boninitic character. The mineralogical and chemical compositions of intrusive rocks also have some similarity with mafic rocks of ophiolite complex of subduction zone.
\end{abstract}

\section{Introduction}

Hornblende-bearing gabbroic rocks (xenoliths and plutons) are fairly common in subduction-related magmatic suite and have been considered to represent magmatic differentiation process in arc magmas (Arculus and Wills 1980; Beard 1986; Yagi and Takeshita 1987; De Bari 1994; Heliker 1995; Hickey-Vargas et al 1995). The presence of hornblende as a dominant phase in gabbroic rocks of subduction zone has been considered either as an early crystallizing mineral from water bearing mafic magmas (Conrad and Kay 1984; Beard and Borgia 1989) or as a product of reaction of early crystallized cumulate (olivine, pyroxene and plagioclase) and water-rich evolved melt/aqueous fluid (Prouteau et al 2001; Costa et al 2002). Hornblende and phlogopite (occasional) bearing gabbroic xenoliths of Volcan San Pedro (Tartara San Pedro Volcanic Complex, Chilean Andes) are the result of multistage differentiation process involving migration of evolved melt \pm aqueous fluid through mafic cumulate pile (Costa et al 2002). This reaction produced high proportion of hornblende (up to $62 \%$ ) in gabbroic rock with high mg-no. and $\mathrm{Cr}_{2} \mathrm{O}_{3}$ content. This type of melt and

Keywords. Chhotanagpur Gneissic Complex; poikilitic hornblende; large-ion lithophile elements; Nb anomaly; subduction. 
aqueous fluid migration, reaction and replacement is also reported from well-known Large Igneous Province like Muscox (Irvine 1980), Skaergaard (McBirney 1995), and Stillwater (Boudreau 1999).

Besides, hornblende is found as a common mineral in gabbroic rocks of ophiolite complexes all over the world (Beard 1986; Beccaluva et al 2004 on Tethyan and Codilleran ophiolite; Bonev and Stampfli 2005 on Evros ophiolite of Greece; Biggazzi et al 1989 on Petrota, W Thrace; Bonev and Stampfli 2008 on Rhodope Magmatic Complex, Bulgaria; Hebert and Laurent 1990 on petrology and geochemistry of arc-related Troodos ophiolite, Cyprus). Gabbroic rocks of subduction zone having ophiolite affinity might be the result of their formation in arc/back arc setting where extensional tectonism caused fracturing and dyke activity. Tholeiitic and boninitic dykes are common in many of ophiolite complexes of arc setting where they are considered as supra-subduction assemblage in marginal basin volcanic arc setting (Frass et al 1990; Magganas et al 1991; Magganas 2002, 2007; Bonev and Stampfli 2005, 2008).

The gabbroic rocks of Paharpur are intrusive into granite gneiss of Chhotanagpur Gneissic Complex $(C G C, \simeq 800-1600 \mathrm{Ma})$ of the eastern Indian Shield. The gabbroic rocks of Paharpur are younger than the granite gneiss of $\mathrm{CGC}$, but no radiometric age is available for them. The high modal abundance of hornblende in gabbroic rocks of Paharpur imparts a peculiar petrographic status. Such hornblende-bearing gabbroic rocks have not been reported from CGC. The petrogenetic process and tectonic setting which favour formation of abundant hornblende in gabbroic rocks appear to be an interesting problem. The present work attempts to characterize the gabbroic rocks and associated dykes of Paharpur and identify the petrotectonic process. This will add knowledge on the evolutionary history of CGC.

Northern part of Puruliya district is characterized by a number of mafic bodies intrusive within CGC. Some of these are associated with their ultramafic counterpart (Mandal et al 2007; Mandal and Ray 2009). The mafic rocks of Paharpur, are considered younger than CGC as evidenced by their intrusive nature and post-tectonic with respect to the shearing movement as evidenced from their undeformed nature. The elliptical gabbro body only shows the effect of shearing at the marginal part along the contacts with the granite country rock which is the result of magmatic flow during emplacement within CGC. The main east-west trending gabbroic body is intruded and cross-cut by a number of dolerite dykes running north-south (five in number). One dolerite dyke trends northeast-southwest and another trends northwest-southeast (figure 1).

The present research work attempts to study the mode of occurrence, petrology and geochemistry of mafic intrusive rocks of Paharpur, Puruliya and West Bengal and understand the magmatic evolution process in an arc-setting.

\section{Geological setting}

The study area forms a part of the Chhotanagpur Gneissic Complex (CGC) and is characterized by the occurrence of medium- to high-grade

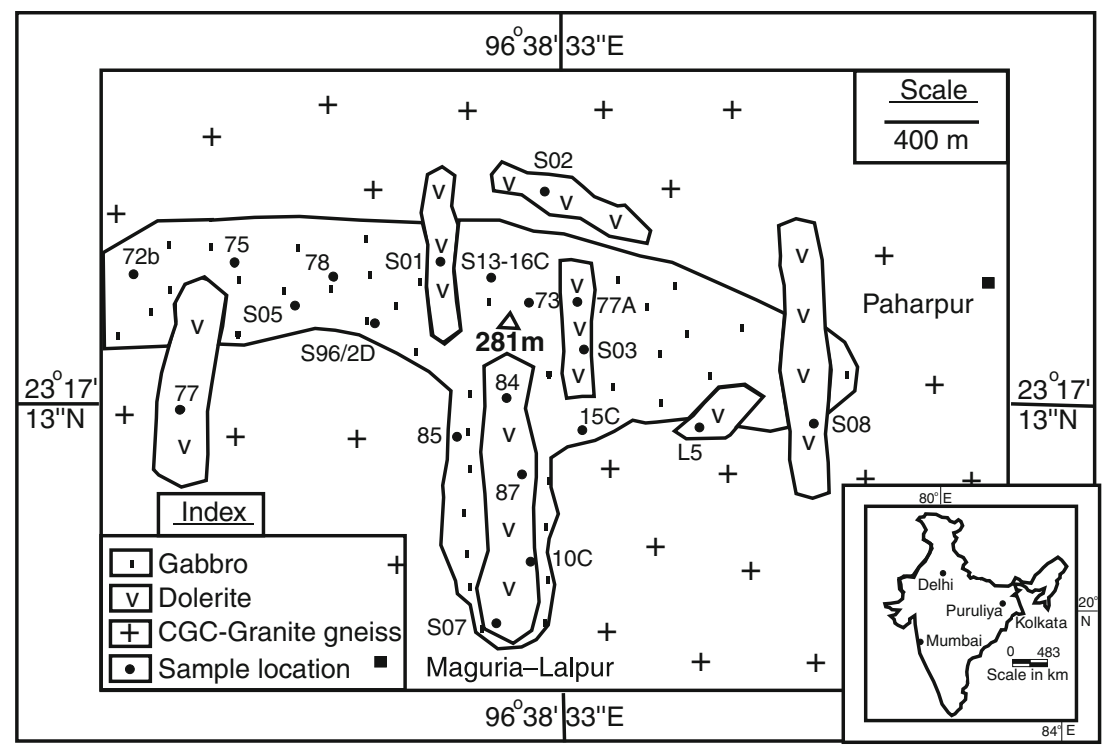

Figure 1. Geological map of the study area around Paharpur. Sample locations are indicated in the map which are analysed for determination of modal and chemical composition of gabbro, dolerite and basalt. 
metamorphic rocks. Intrusive rocks such as porphyritic granite, gabbro and dolerite are found as concordant and discordant intrusions within CGC. Available geochronological data based on $\mathrm{K} /$ Ar method of biotites from porphyritic granitoid gneiss and muscovite from leucogranitoid assign ages of $870 \pm 40 \mathrm{Ma}$, and $810 \pm 40 \mathrm{Ma}$, respectively (Baidya et al 1987a, 1987b). Rb/Sr method assigns ages of $1071 \pm 64 \mathrm{Ma}$ for porphyritic hypersthene granite near Raghunathpur, NE Puruliya and $1178 \pm 61$ Ma for migmatites from Murguma, SE Puruliya, Ray Barman et al 1994). U-Pb dating of zircon from the Bengal anorthosite from further east which is the part of a deformed and metamorphosed gabbro-anothosite-layered complex assigns a Mesoproterozoic age $(\sim 1550 \mathrm{Ma})$ - an early magmatic event in the CGC (Ghosh and Chatterjee 2008). Gabbroic rocks of Paharpur are undeformed with no effect of metamorphism and have no spatial and temporal relationship with those of Bengal anorthosites of Bankura which occur in the eastern part of CGC. The Bengal anorthosite of Mesoproterzoic age is intimately associated (often interlayered) with gabbroic rocks both of which are deformed, metamorphosed and strongly foliated. The undeformed, unmetamorphosed massive gabbroic rocks of Paharpur are definitely younger than Bengal anorthosite, but their actual age cannot be ascertained as no age data is available in existing literature. A general $\mathrm{E}-\mathrm{W}$ strike with northerly dip of the foliation is the dominant fabric of the granitoid gneisses of the CGC (Sengupta and Sarkar 1964; Ghosh 1983; Mazumder 1988; Sarkar 1988; Baidya et al 1987a, 1987b). The monotonous northerly dips may be ascribed to isoclinal folds with overturned southern limb in the present area.

Precambrian rocks of the area have undergone three phases of folding (Baidya et al 1987a, 1987b). The last phase of deformation in the area is represented by the development of a set of shear zones. The most prominent of these is the southernmost one and is known as the North Puruliya Shear Zone (NPSZ). Other E-W trending shear zones are also observed in the southern part of the NPSZ. One shear zone $(\mathrm{E}-\mathrm{W})$ is observed just to the south of the study area affecting granite gneiss. The main gabbroic masses as well as the intrusive dykes are not affected by this $\mathrm{E}-\mathrm{W}$ shearing as these rocks do not have shear-related E-W foliation. They are dominantly massive. The northern margin of the gabbroic body shows crude E-W foliation. These foliations, primary in nature, possibly have developed at the time of its emplacement.

The main intrusive body of Paharpur is a gabbroic mass (running E-W, paralleling the foliation of granitic country rock) of more or less elliptical outline $(1500 \times 500 \mathrm{~m})$ with two ends tapered and is intruded by a number of dykes of doleritic composition trending mostly $\mathrm{N}-\mathrm{S}$ (average width $15 \mathrm{~m}$ ). Thus, it is found that the general orientation of these younger dolerite dykes is at a high angle (almost 90 degree) with the elongation of the gabbroic body.

\section{Petrography and mineral composition}

The optical properties of minerals and their textural relationships have been studied using a high resolution NIKON polarizing microscope (model no. 064333) at the Department of Geology, Presidency University. Mineral composition has been determined at the EPMA Lab, CPL, CHQ, Geological Survey of India, Kolkata. Analyses were performed with a $15 \mathrm{KV}$ accelerating voltage, $15 \times$ $10^{-10} \mathrm{~A}$ beam current, $5 \mu \mathrm{m}$ spot size and $50 \mathrm{~s}$ live time for each element. Mineral compositions were determined with CAMECA $S \times 100$. Natural mineral standards were used for all elements except $\mathrm{Mn}$ and $\mathrm{Ti}$, for which synthetic standards were used. The analyses were standardized using natural standards supplied by SPI Suppliers, Structure Probe Inc., Canada. The replicate analyses showed identical results. Precision of analyses is within the error limit of $\pm 3 \%$.

The main gabbroic rocks are greyish green, coarse-grained and porphyritic. A number of dolerite dykes, later formed, trending roughly $\mathrm{N}-\mathrm{S}$, intrude this main gabbroic body, outcrop in northern and southern flanks. Another E-W trending dyke is outcropping at the northernmost part of the intrusive and two others running N-S at its eastern and western sides (figure 1). The dykes are medium-grained, porphyritic and at places with mineral lineation and slickensides.

The huge gabbroic intrusive consists mainly of plagioclase, hornblende, pyroxenes, apatite and some opaque minerals such as magnetite, hematite and rutile.

Plagioclase $\left(\mathrm{An}_{51}-\mathrm{An}_{90}\right.$, table 1$)$ is coarse, tabular and lath-shaped together with medium-sized aggregates. They occupy up to $45 \%$ (by volume) of the rocks and range in composition from andesine to bytonite. Relic laths and equant grains of plagioclase $\left(\mathrm{An}_{51}\right)$ are poikilitically enclosed within large plates of hornblende in gabbro. At places, plagioclase is resorbed by hornblende.

Hornblende occupies around $60 \%$ of the rock and shows different schemes of pleochroism from colourless to light green and green to greenish brown. Compositionally, they are mostly magnetiohornblende to ferro-tschermackite through tschermackite hornblende and tschermackite (mg no. 6573 , table 2, figure 2). Primary hornblende grains are discrete, small, subhedral and fewer in number. Hornblende in Paharpur gabbro occurs mostly 


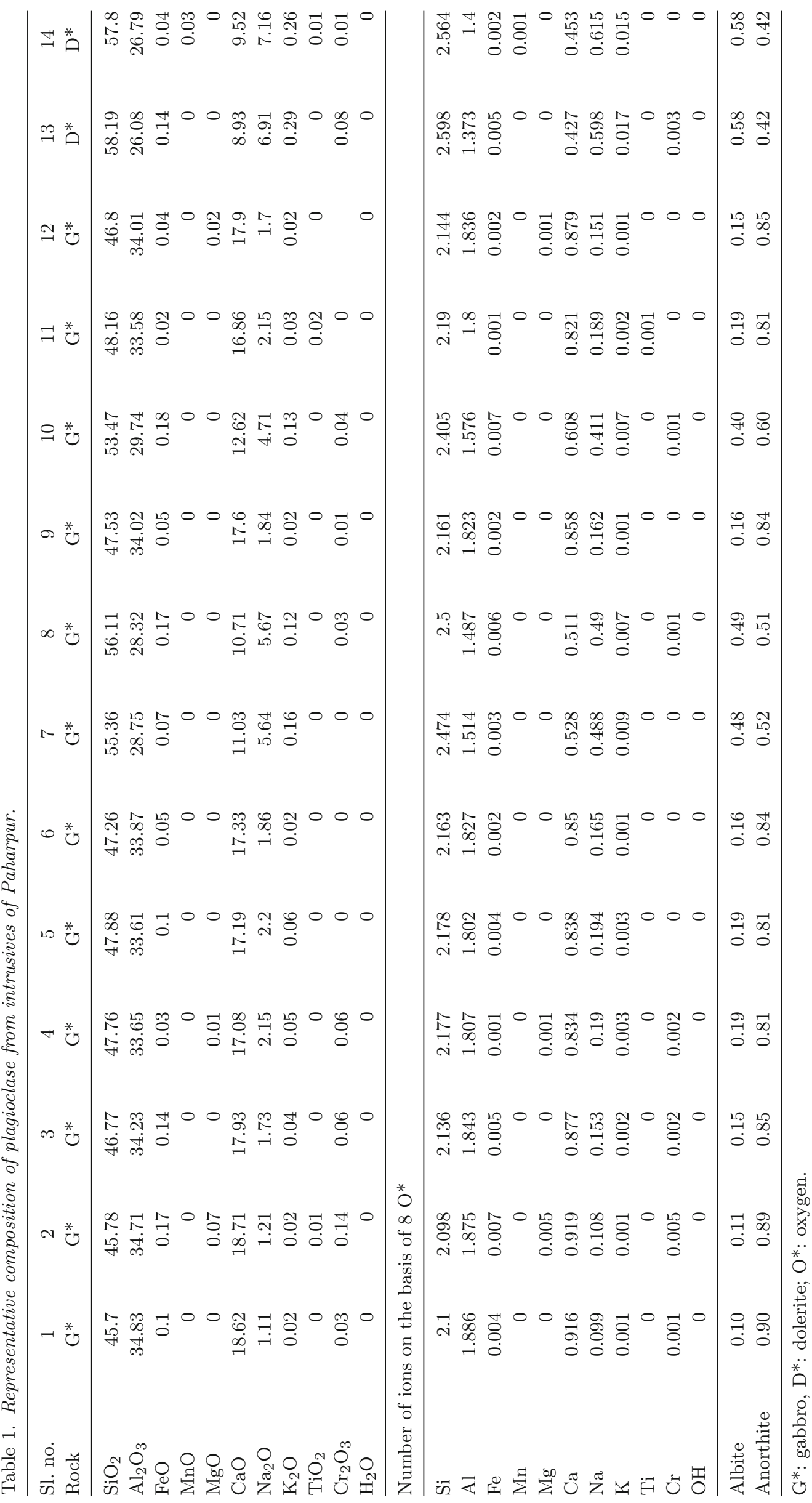




\begin{tabular}{|c|c|c|c|}
\hline$\bumpeq \stackrel{*}{\oplus}$ & 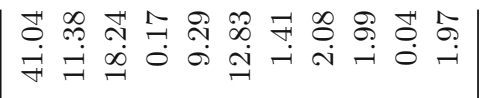 & & 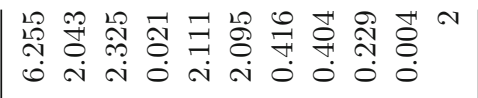 \\
\hline$\stackrel{\bullet}{\bullet}$ & 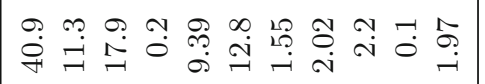 & & 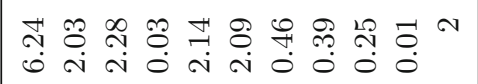 \\
\hline$\stackrel{*}{*}$ & 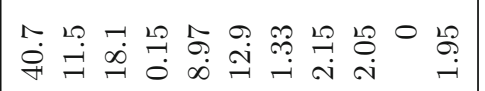 & & 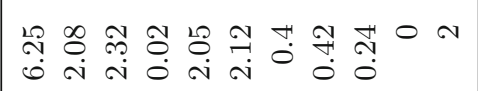 \\
\hline$\underset{\unlhd}{*}$ & 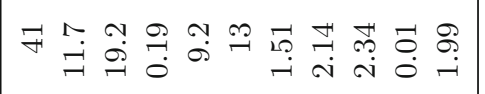 & & 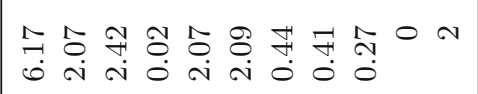 \\
\hline$\stackrel{*}{*}$ & 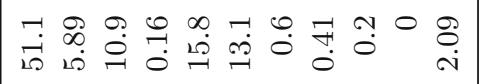 & & 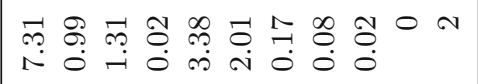 \\
\hline$\stackrel{*}{\mho}$ & 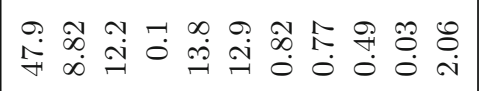 & & 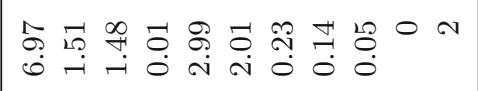 \\
\hline$\exists$ ש & 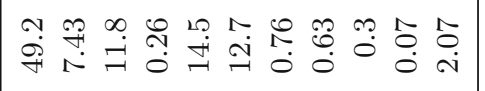 & & 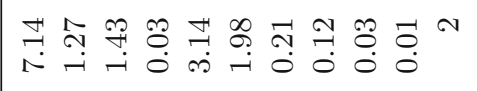 \\
\hline$\stackrel{*}{*}$ & 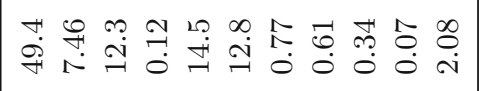 & & 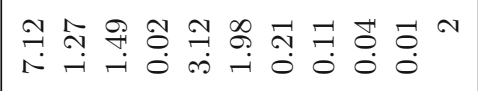 \\
\hline の & 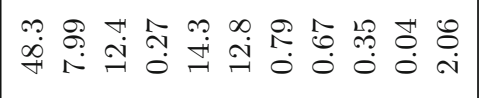 & & 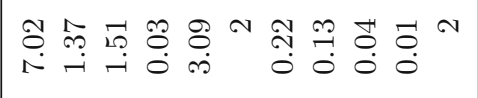 \\
\hline$\infty \stackrel{*}{\mho}$ & 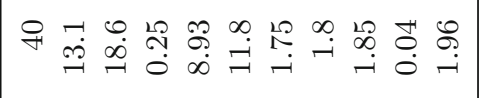 & & 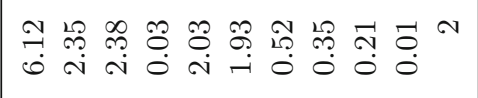 \\
\hline ^ & 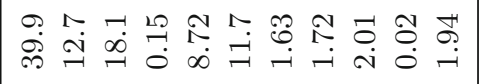 & & 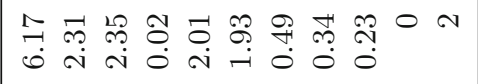 \\
\hline$\bullet \stackrel{*}{\circlearrowright}$ & 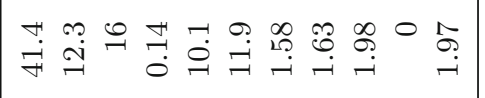 & & 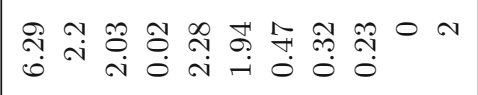 \\
\hline$\llcorner\stackrel{*}{\circlearrowright}$ & 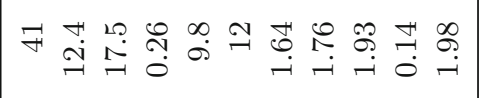 & & 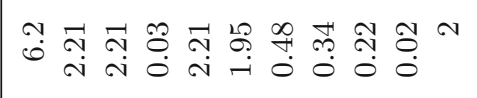 \\
\hline$\forall \stackrel{*}{\mho}$ & 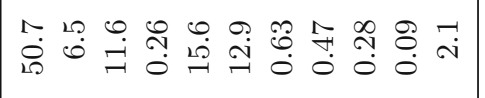 & & 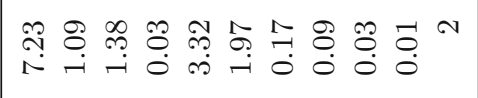 \\
\hline$\infty \stackrel{*}{*}$ & 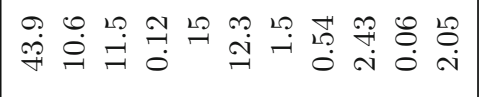 & & 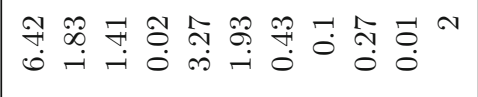 \\
\hline ง $\stackrel{*}{\circlearrowright}$ & 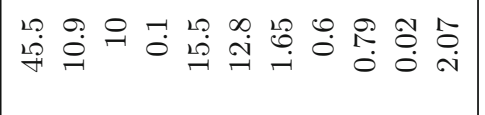 & 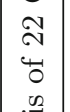 & 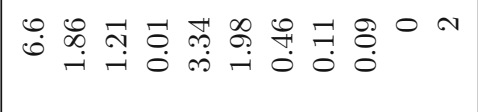 \\
\hline$\neg \stackrel{*}{\circlearrowright}$ & 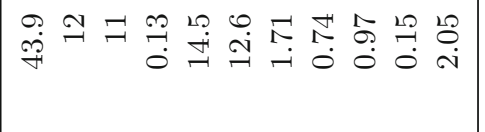 & 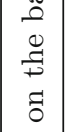 & 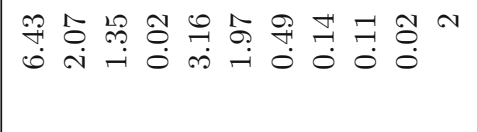 \\
\hline 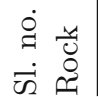 & 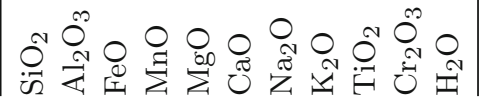 & 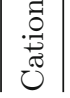 & 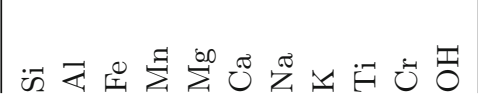 \\
\hline
\end{tabular}




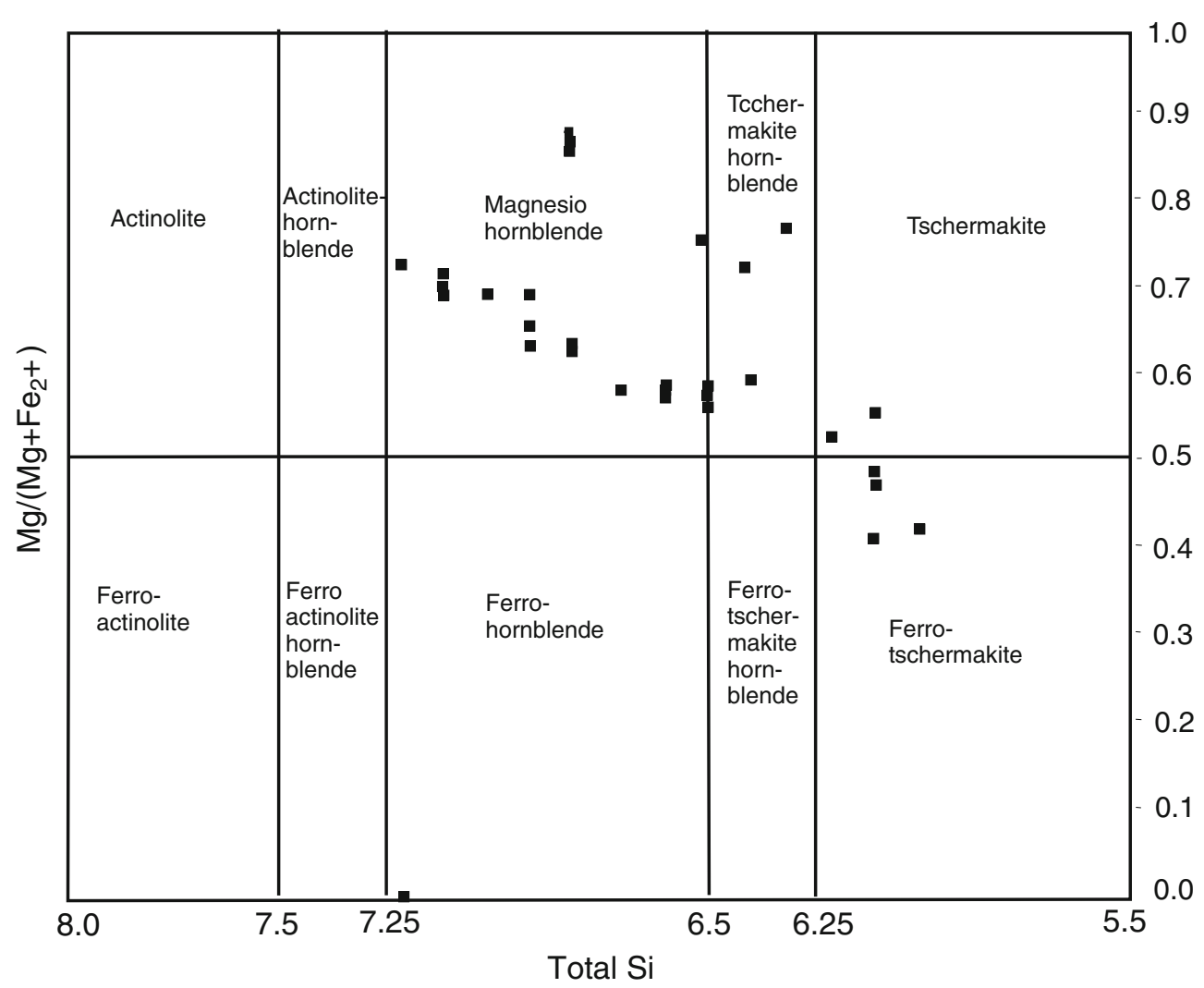

Figure 2. Representative amphibole composition of intrusives of Paharpur. Black-filled squares represent the amphibole compositions.

as secondary grains as evident from their irregular, rim-like occurrences and large; anhedral character. Secondary hornblendes are thought to have formed due to alteration of pyroxenes and plagioclases. In two samples of dolerite (77, 77A), pyroxene grains are almost completely replaced by hornblende. At places, hornblende is very large in size, forming large phenocryst embedded in a relatively fine ground mass of plagioclase and pyroxene. This type of texture attributes to a porphyritic nature of the rock. Opaque minerals are also present as inclusion within hornblende. At some places, hornblende occurs as large enclosing grain within which small pyroxene, ilmenite and euhedral plagioclase grains are floating as discrete grains. This type of hornblende grain is defined as 'poikilitic hornblende' (figure 3).

Pyroxenes are of two types. Clinopyroxene is more abundant (10\% to $30 \%, \mathrm{mg}$ no. $72-82$ ). They occur as medium-to-coarse subhedral grains frequently replaced by hornblende. Some grains contain schiller plates. These are mostly diopsidic in composition ( $\mathrm{Wo}_{48} \mathrm{En}_{40} \mathrm{Fs}_{12}-\mathrm{Wo}_{50} \mathrm{En}_{43} \mathrm{Fs}_{07}$, table 3 ). Orthopyroxenes (pleochroic from pale pink to pale green) are very small in abundance (0.5-2\%) and frequently crowded with fine pinkish brown dusts. These are mostly hypersthene and bronzite in composition $\left(\mathrm{En}_{60}-\mathrm{En}_{79}\right.$, table 4$)$. At places, pyroxenes are only partly altered along grain boundary to hornblende which occurs as reaction rim. At places, alteration occurs along both boundary and cleavage planes, so that the remaining

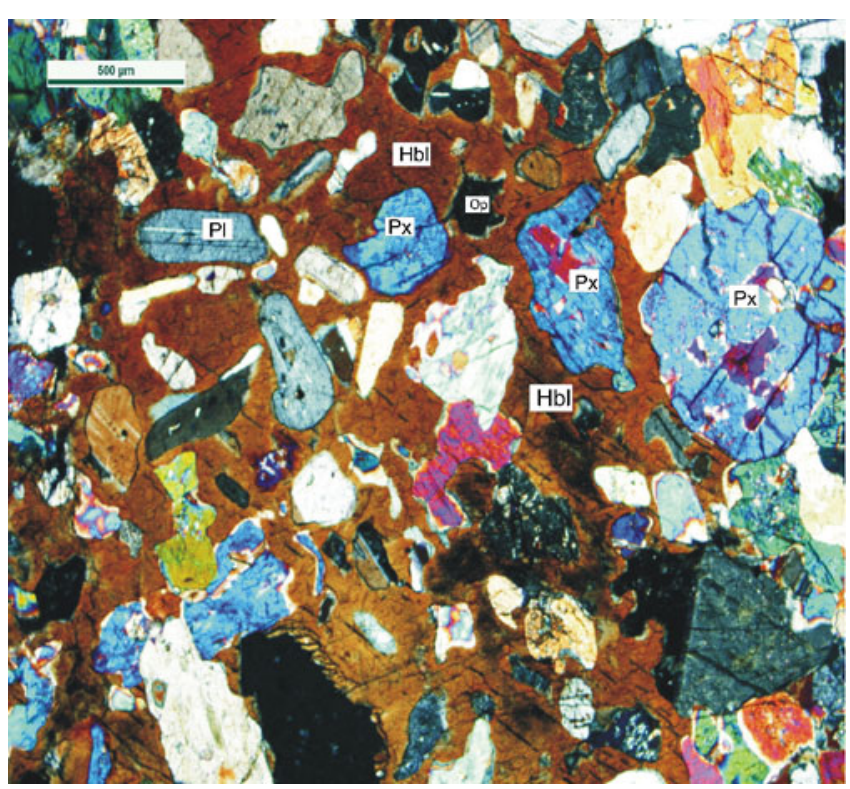

Figure 3. Poikilitic hornblende (brown) enclosing early formed plagioclase and pyroxene grains. Hbl - Hornblende, $\mathrm{Pl}$ - Plagioclase, Px - Pyroxene, Op - Opaque. 


\begin{tabular}{|c|c|c|c|c|}
\hline$\stackrel{*}{\circ}$ & 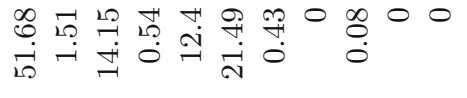 & & 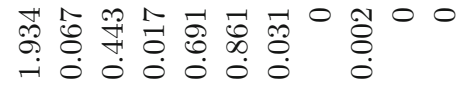 & ‡. \\
\hline$\stackrel{\text { ID }}{\rightarrow} \stackrel{*}{\ominus}$ & 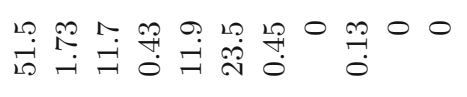 & & 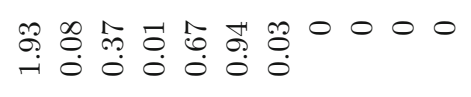 & 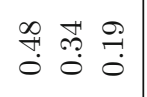 \\
\hline$\underset{\sim}{*} \stackrel{*}{\oplus}$ & 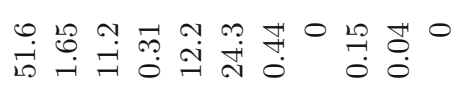 & & 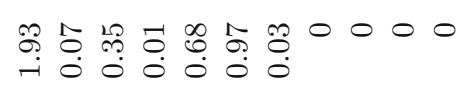 & 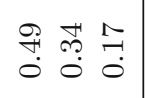 \\
\hline$\stackrel{*}{*}$ & 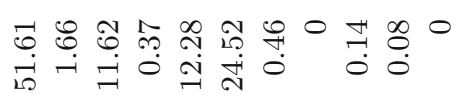 & & 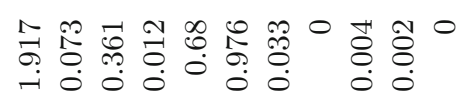 & 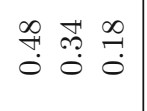 \\
\hline ฯ & 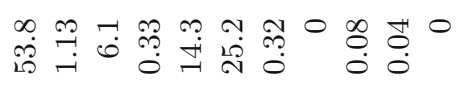 & & 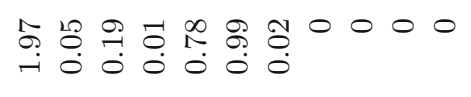 & 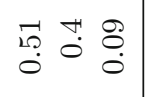 \\
\hline$=\stackrel{*}{0}$ & 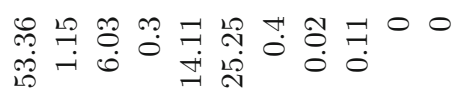 & & 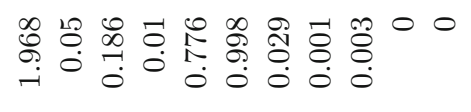 & 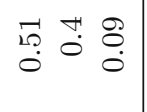 \\
\hline 은 & 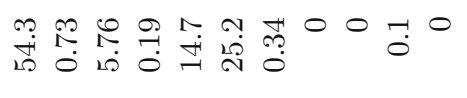 & & 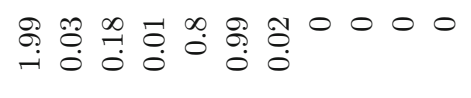 & 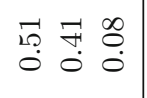 \\
\hline o & 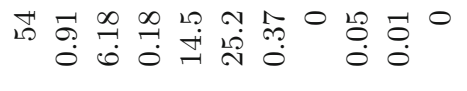 & & 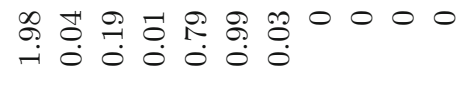 & $\begin{array}{lll}\overrightarrow{1} . & 7 & 8 \\
0 & \forall \\
0 & 0 \\
0\end{array}$ \\
\hline$\infty \stackrel{*}{U}$ & 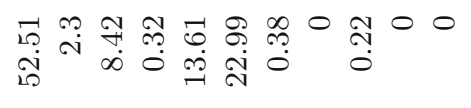 & & 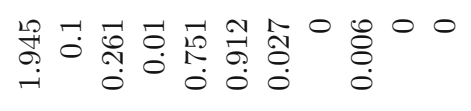 & $\stackrel{\infty}{\sharp} \stackrel{\sharp}{0} \stackrel{7}{7}$ \\
\hline ^ & 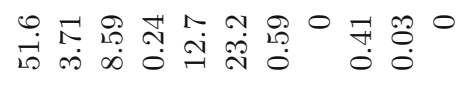 & & 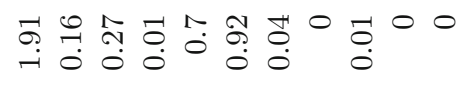 & 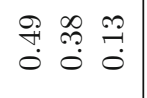 \\
\hline ○ & 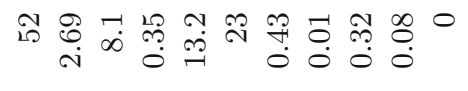 & & 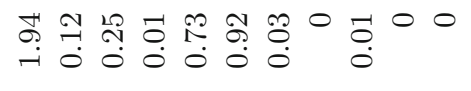 & भi \\
\hline L & 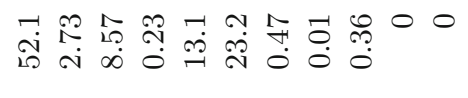 & & 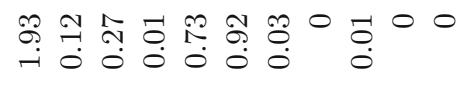 & 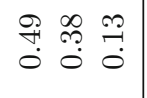 \\
\hline$\forall \stackrel{*}{0}$ & 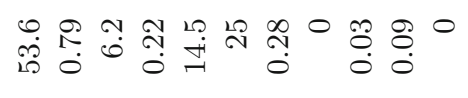 & & 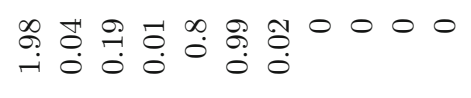 & 요 $\underset{0}{7} \underset{0}{7} \stackrel{8}{0}$ \\
\hline ڤ & 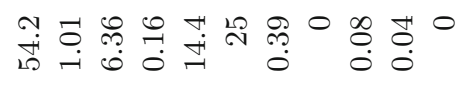 & & 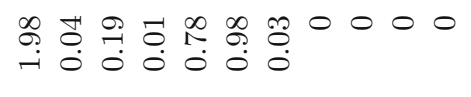 & 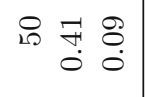 \\
\hline N & 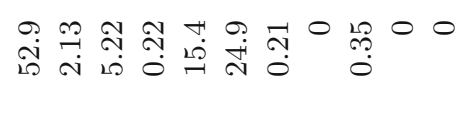 & $\begin{array}{l}0 \\
+ \\
0 \\
.0 \\
\frac{\pi}{\pi} \\
0\end{array}$ & 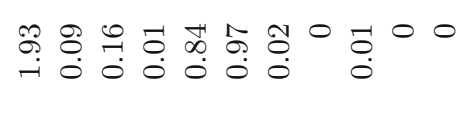 & 路算 \\
\hline 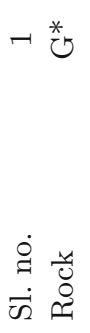 & 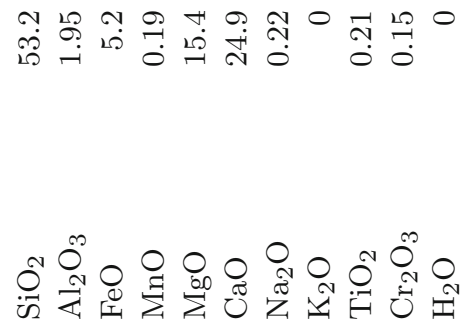 & 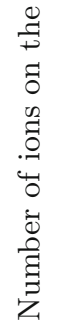 & 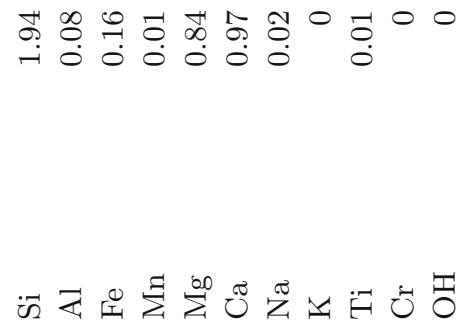 & 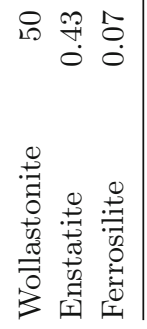 \\
\hline
\end{tabular}




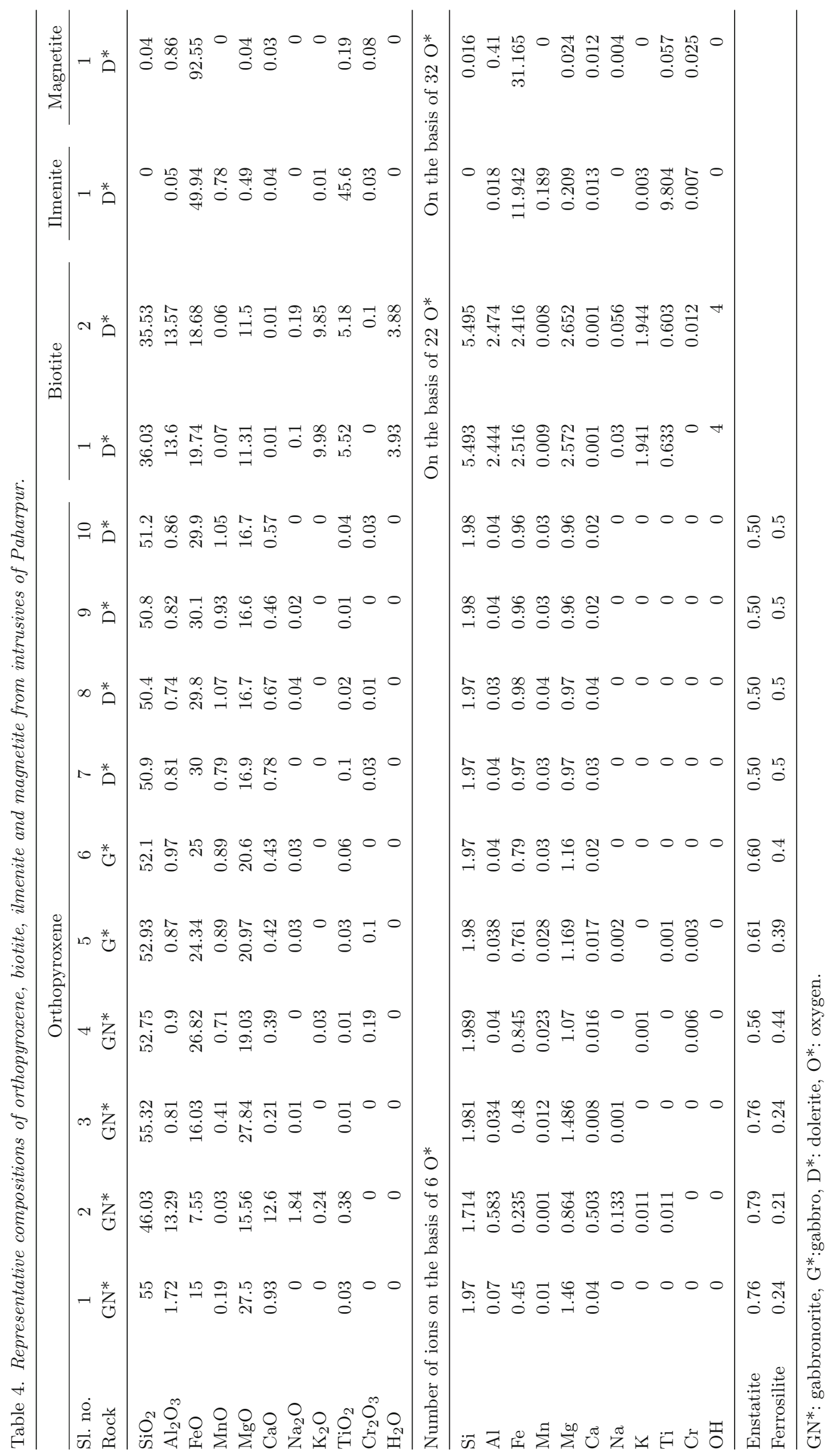


pyroxene looks greenish, resembling hornblende. At other places, pyroxenes are totally replaced by hornblende, so that there are no pyroxene grains; only occurrence of hornblende and their nature suggest that they are alteration products.

Apatites are rare and occur as small to mediumsized, elliptical grains generally associated with pyroxene and opaque minerals.

Phlogopite is less-abundant in these rocks, only a few grains are observed.

Rutile occurs as patchy grains with brilliant reddish brown colour associated with plagioclase and hornblende.

Opaque minerals occur in the form of ilmenite (subhedral) and a few magnetite (euhedral) associated with pyroxene and hornblende.

Texturally, the main gabbroic mass is characterized by porphyritic and poikilitic texture.

Dolerite dykes are composed mainly of plagioclase-pyroxene-hornblende with subordinate amount of olivine, rutile and opaque.

Plagioclase $\left(\mathrm{An}_{42}\right.$, table 1$)$ occurs as criss-cross medium-sized laths forming triangular and polygonal spaces filled up by anhedral pyroxenes and opaques giving rise to intergranular texture.

Pyroxenes occur both in the form of orthopyroxene (hypersthene) and clinopyroxene (diopsidesalite). Orthopyroxene is $\mathrm{En}_{50} \mathrm{Fs}_{50}$ (table 4) and clinopyroxene varies from $\mathrm{Wo}_{43} \mathrm{En}_{35} \mathrm{Fs}_{22}$ to $\mathrm{Wo}_{49} \mathrm{En}_{34} \mathrm{Fs}_{17}$ in composition (table 3). They occur as elongate (generally orthopyroxene) and subhedral equant (generally clinopyroxene) grains. The elongate grains follow the longer contact of plagioclase laths. Pyroxene occurs as thin reaction rims around olivine. Individual grains of hypersthene (pleochroic from pale green to pale pink) are crowded with numerous tiny pinkish-brown dusts. Some pyroxene grains contain schiller plates and also extremely fine needles of opaque along the prismatic cleavage giving turbidity to the grains.

Olivines occur as medium-sized rounded grains successively surrounded by coronas of orthopyroxene, brownish hornblende and spongy actinolite; the latter being in contact with the lath-shaped plagioclase. The rimmed olivine grain, in the core of the above corona is at many places represented by black dusts and highly irregular grains of magnetite, some of which have filled up the cracks.

Hornblende $(\mathrm{X}=$ yellowish green, $\mathrm{Y}=$ dirty green, $\mathrm{Z}=$ brownish green; $\mathrm{Z}_{C}^{\prime}=20^{\circ}$ ) is medium-grained, anhedral to subhedral. They are mostly magnesiohornblende (figure 2, table 2) in composition. Brownish hornblende frequently has replaced coarser pyroxenes either forming corona along the contact with plagioclase laths or forming irregular patches within pyroxenes. In many cases of such replacement, minute opaque grains are intimately associated with hornblende-pyroxene aggregate.

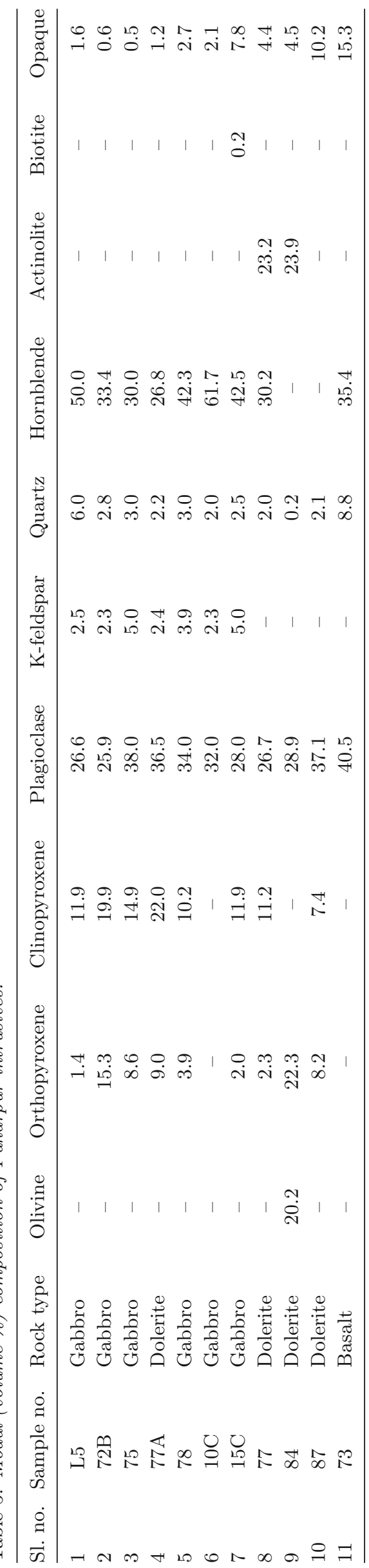




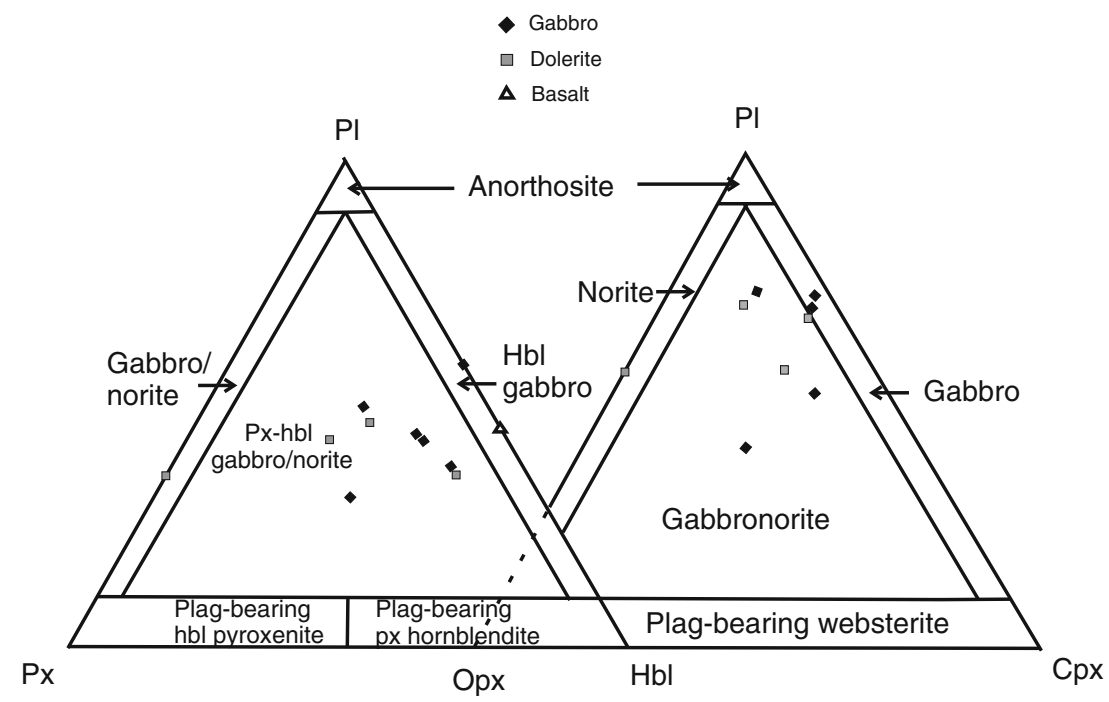

Figure 4. Modal classification of intrusives of Paharpur after Streckeisen (1973).

Biotites are rare (table 4$)$.

Rutile is patchy and its rare occurrence is seen to be associated with hornblende and plagioclase.

Opaques are mainly ilmenite with occasional magnetite (table 4). In most of the cases, it occurs as fine flakes and fills the fractures in rimmed olivine.

In most of the cases, dolerites show intergranular texture. Some finer-grained dolerites show mineral lineation.

Modal analysis of gabbroic intrusives and younger dolerite dykes of Paharpur has been carried out using automatic point counter and the modal composition is given in table 5. Using the modal proportion of plagioclase, orthopyroxene, clinopyroxene and hornblende, gabbroic and doleritic rocks have been classified (figure 4) using the IUGS scheme (Streckeisen 1973). Intrusive rocks have been identified as gabbronorite/hornblende gabbronorite.

\section{Geochemistry}

Major trace (including rare earth) element composition of eight samples of gabbroic rocks were determined at the Chemical Division, Geological Survey of India, Kolkata using XRF and another eight from National Geophysical Research Institute, Hyderabad using XRF and ICP-MS. International rock standards such as BHVO, JB 2 for major element and trace elements respectively, were also run along with the samples to check precision and accuracy of measurement. The certified and analysed values of $\mathrm{BHVO}$ and JB 2 are given in the tables (tables 6 and 7 ) along with major and trace element abundances of samples to check the error limits of measurement.
In the following section, the major, minor and trace element content of mafic intrusives of Paharpur are discussed with the help of suitable diagrams and some of the chemical parameters of these mafic rocks are compared with those of Mid-oceanic Ridge Basalt (MORB), island-arc tholeiite (IAT) and calc-alkaline basalt (CAB) (Wilson 1989).

Porphyritic gabbro shows $\mathrm{SiO}_{2}$ content ranging between $44.57 \%$ and $52.28 \%$. MgO content is fairly high and ranges from $8.55 \%$ to $15.65 \%$. On the other hand, $\mathrm{Al}_{2} \mathrm{O}_{3}$ content varies from $6.79 \%$ to $18.92 \%$. CaO content is high $(10.15 \%$ to $17.26 \%)$. $\mathrm{K}_{2} \mathrm{O}$ content of gabbroic rock ranges from $0.07 \%$ to $0.63 \%$. $\mathrm{TiO}_{2}$ content is fairly low and varies from $0.38 \%$ to $1.88 \%$. $\mathrm{P}_{2} \mathrm{O}_{5}$ ranges from $0.04 \%$ to $1.0 \%$. High $\mathrm{MgO}(>8 \%), \mathrm{SiO}_{2}(>50 \%)$ and low $\mathrm{TiO}_{2}$ $(0.4 \%)$ content imparts a boninitic character with high Ca content.

Trace element abundances (including compatible and incompatible elements) are variable. Among the incompatible elements, $\mathrm{Zr}$ abundances are highly variable. Gabbroic intrusive shows much lower abundances of $\mathrm{Zr}$ value (14.5-56.8 ppm). $\mathrm{Y}$ shows restricted range of distribution from 10 to $23.6 \mathrm{ppm}$. Gabbroic intrusive has $\mathrm{Rb}$ content of $6.1-37.6 \mathrm{ppm}$. Sr shows a very wide range of variation from 111.2 to $582.1 \mathrm{ppm}$. Incompatible elements (Zr, Y, Rb) show low abundance. The abundance of compatible elements $(\mathrm{Ni}, \mathrm{Co}, \mathrm{Cr})$ is variable in different parts of the gabbroic intrusive. $\mathrm{Ni}$ content varies from 19.1 to $165.5 \mathrm{ppm}$ and $\mathrm{Cr}$ content ranges from 32.3 to $570.5 \mathrm{ppm}$. Overall, the gabbroic body shows enrichment in $\mathrm{Rb}, \mathrm{Th}, \mathrm{Ba}, \mathrm{Sr}$ and depletion in $\mathrm{Nb}$ and $\mathrm{Zr}$ compared to average MORB (Wilson 1989), this chemical characteristic is very much similar to the Dhanjori mafic volcanic rocks from adjacent Singbhum region (Roy et al 2002). 


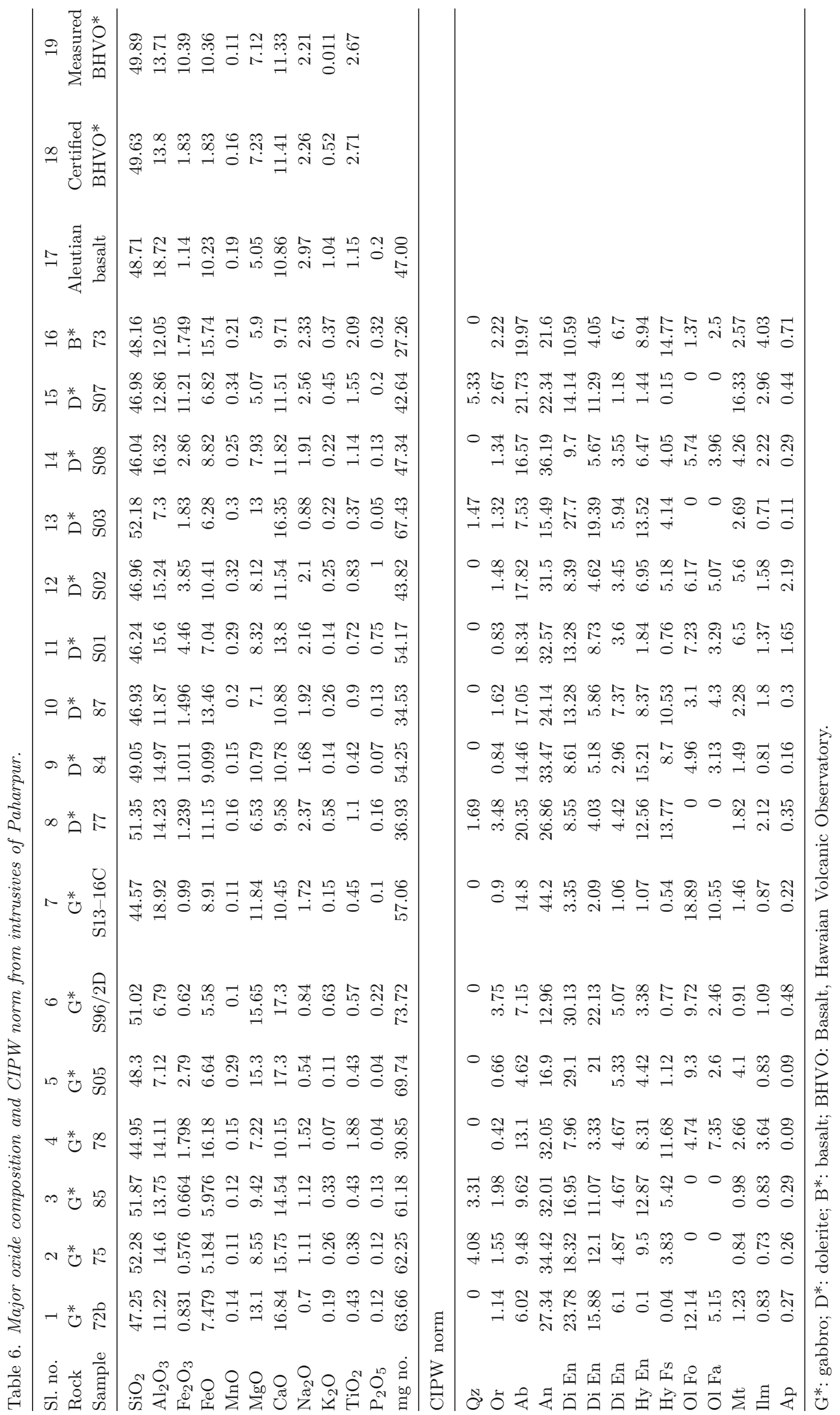




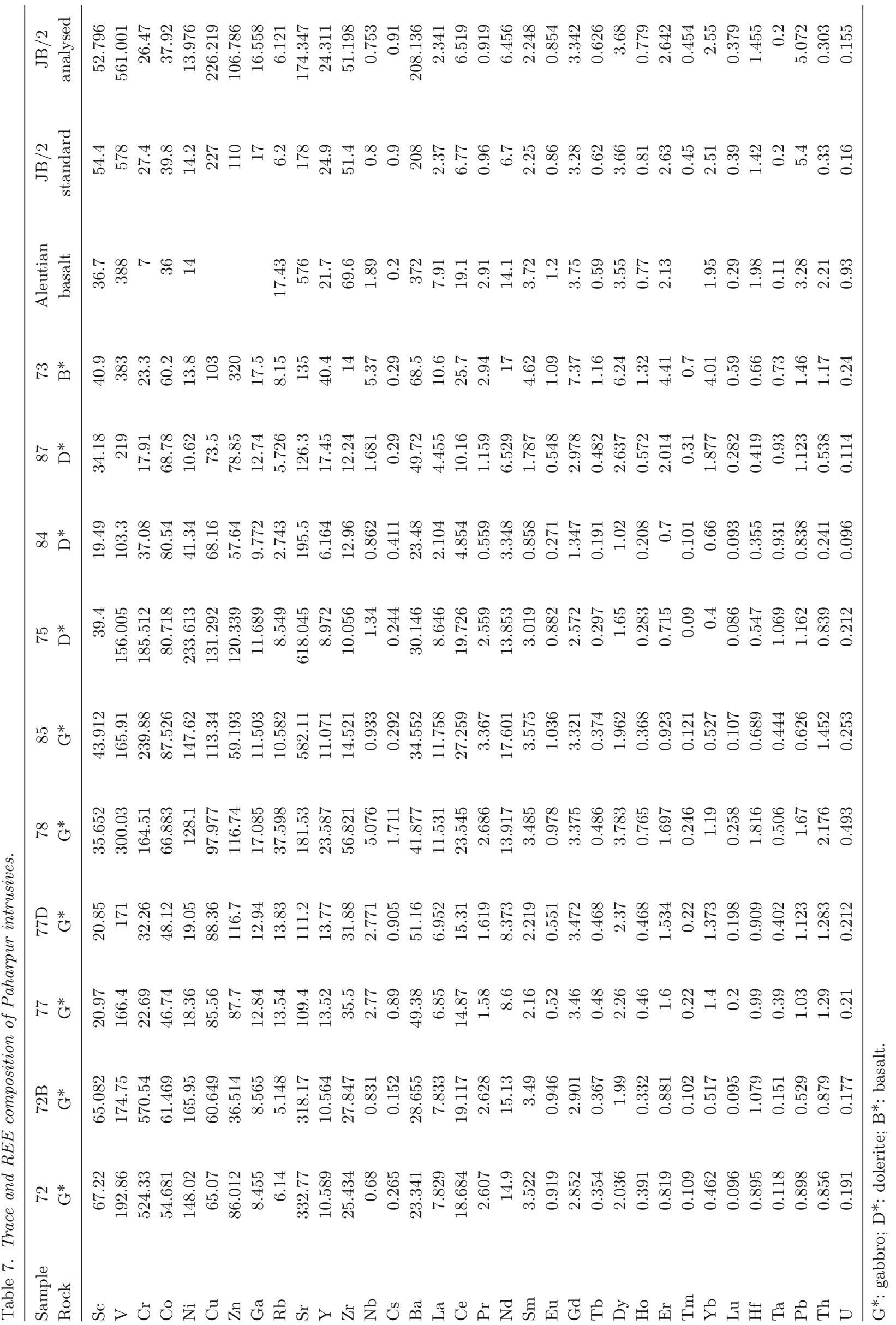




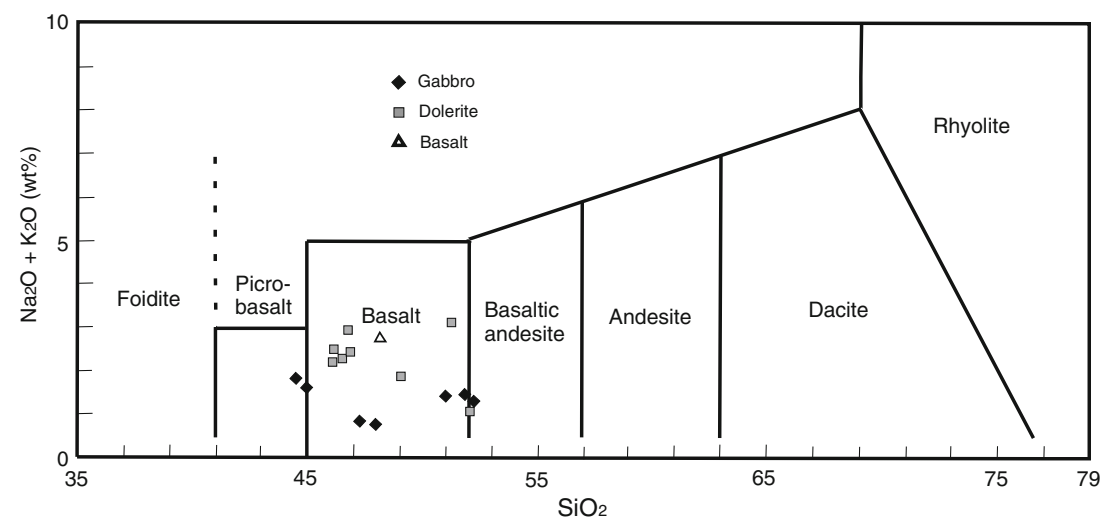

Figure 5. Total alkali vs. silica diagram of intrusives of Paharpur, after LeBas and Streckeisen (1991).

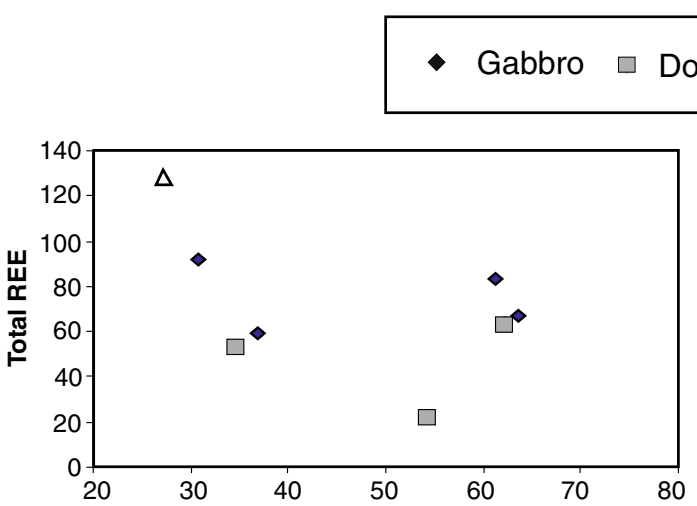

\section{$\Delta$ Basalt}
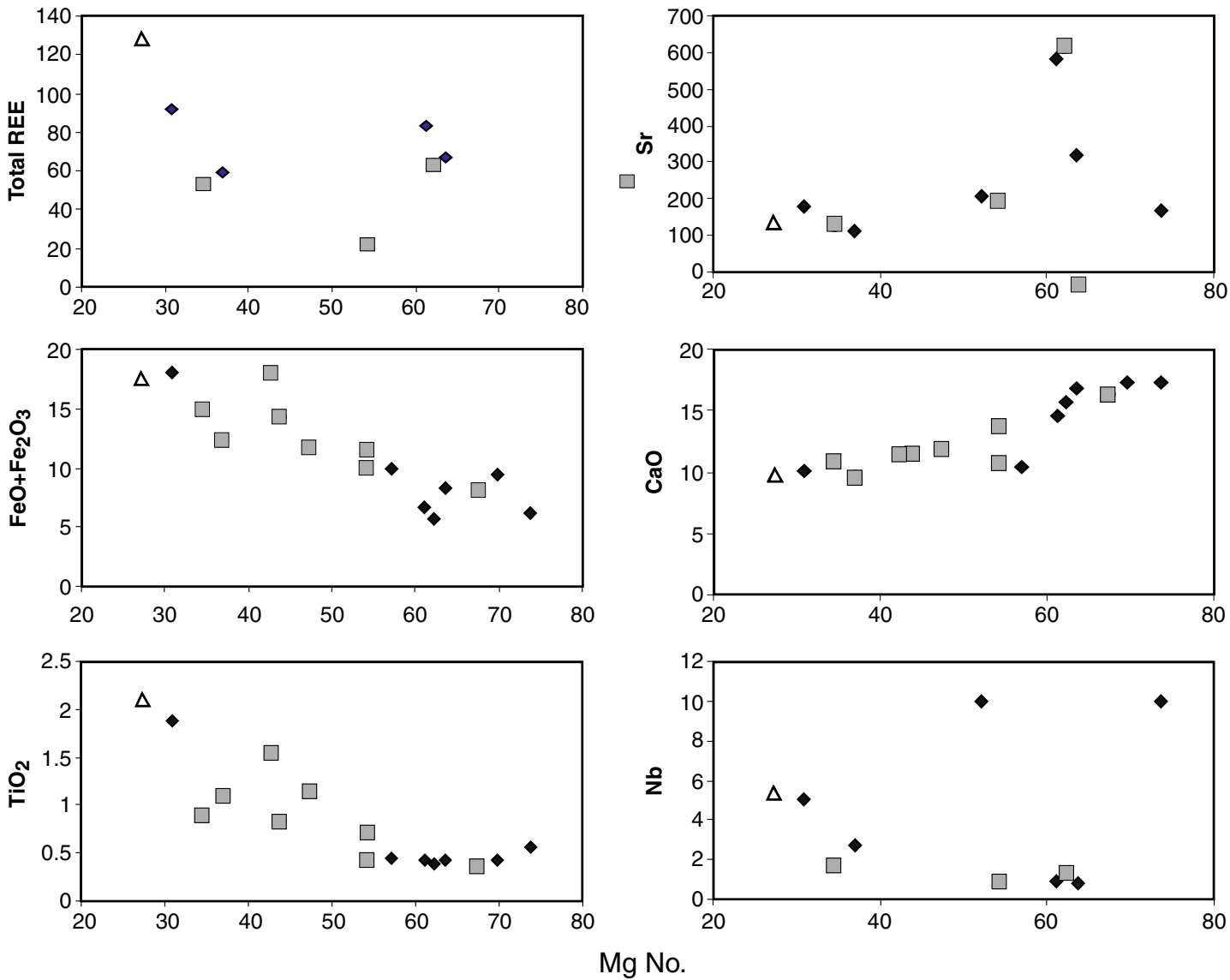

Figure 6. Mg no. variation diagram of intrusives of Paharpur (major element oxides in percent and trace element in ppm).

On the other hand, the later formed dolerite dykes show silica range from $46.24 \%$ to $52.18 \%$. $\mathrm{MgO}$ content is highly variable and ranges from $5.9 \%$ to $13 \%$. $\mathrm{CaO}$ content is high (9.71-16.35\%). Within these dykes, one sample with high $\mathrm{SiO}_{2}$, $\mathrm{MgO}, \mathrm{CaO}$ and low $\mathrm{TiO}_{2}\left(\mathrm{SiO}_{2} 52.18 \%, \mathrm{MgO} 13 \%\right.$,
$\mathrm{TiO}_{2} \quad 0.37 \%$ and $\mathrm{CaO} 16.35 \%$ ) appears to show a boninitic character while other samples are of tholeiitic affinity.

Trace element abundances of the dolerite dykes are also variable similar to the main gabbroic mass. $\mathrm{Zr}$ ranges from 10.1 to $14 \mathrm{ppm}$. Rb ranges between 
2.7 and $8.5 \mathrm{ppm}$. Sr shows a high range of 126.3 to $618.1 \mathrm{ppm}$. Within the compatible elements, $\mathrm{Ni}$ ranges between 10.6 and $233.6 \mathrm{ppm}$, whereas $\mathrm{Cr}$ content ranges from 17.9 to $185.5 \mathrm{ppm}$.

Basaltic component of the mafic clan shows low $\mathrm{SiO}_{2}$ content $(48.16 \%)$. All the other oxides are comparable with associated gabbro and dolerite. This basaltic rocks show unusually high $\mathrm{FeO}$ (15.74\%) and low $\mathrm{MgO}(5.9 \%)$.

Similar pattern of abundance (such as that of gabbro) of trace elements is shown both by dolerite and basalt.

The Paharpur intrusives when classified according to TAS (total alkali vs. silica) diagram (figure 5, after LeBas and Streckeisen 1991), are found to lie mostly (14 out of 16) within the field of basalt with one in picro-basalt field and one in basaltic andesite field.

In mg no. variation diagram (figure 6), the intrusives show a clear positive correlation with $\mathrm{CaO}$, $\mathrm{Ni}$ and $\mathrm{Sr}$, whereas total iron, total REE and $\mathrm{TiO}_{2}$ show a good negative correlation. In AFM $\left(\mathrm{A}=\mathrm{Na}_{2} \mathrm{O}+\mathrm{K}_{2} \mathrm{O} ; \mathrm{F}=\mathrm{FeO}+\mathrm{Fe}_{2} \mathrm{O}_{3} ; \mathrm{M}=\mathrm{MgO} ;\right)$ diagram (figure 7, after Brown 1982), Paharpur intrusives follow precisely (15 out of 16 ) the tholeiitic trend confirming a well-differentiated magmatic character which forms under low oxygen fugacity condition. It prevents iron in the magma to precipitate as oxide phase and its entry into silicate structure is prolonged to define an iron-enrichment trend or tholeiite trend (Bose 1997).

In chondrite-normalized REE diagram (figure 8, chondrite data after Sun and McDonough 1989),

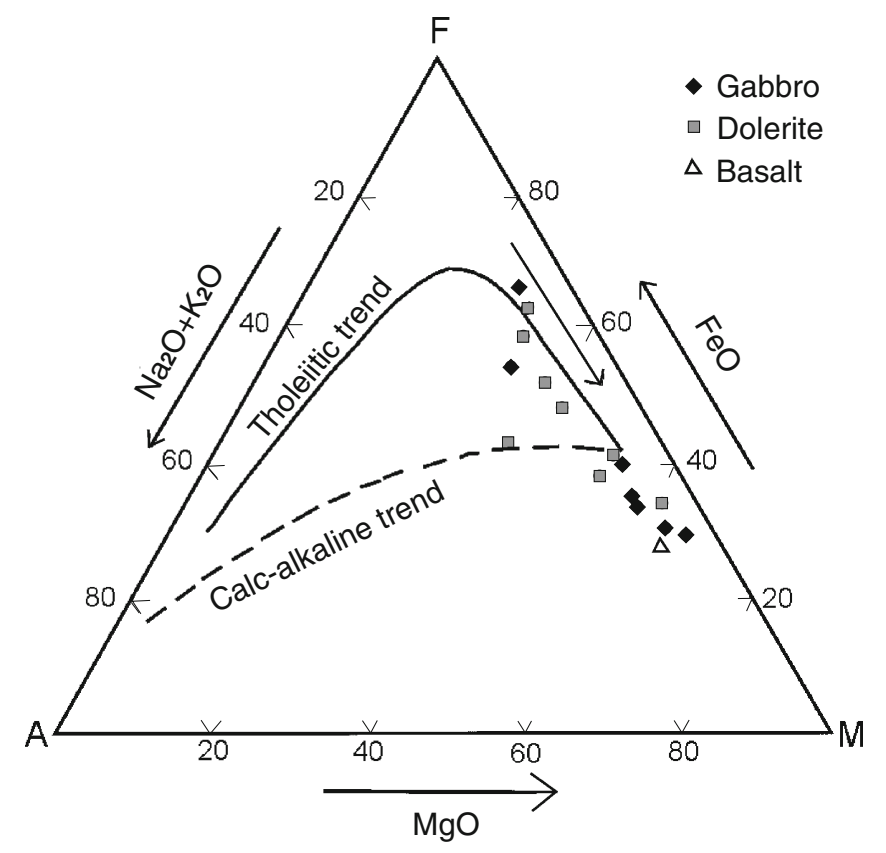

Figure 7. AFM diagram of intrusives of Paharpur, after Brown (1982). all the intrusives including gabbro and dolerite show flat to slightly LREE-fractionated pattern and variable degree of overall REE enrichment with respect to the abundance in chondrite. Gabbro has higher overall abundance of REE and more pronounced LREE-fractionated REE pattern than dolerite. In basaltic dyke, no fractionation is observed. Most of the samples of dolerite and basalt show distinct Eu anomaly, whereas gabbro do not show appreciable Eu anomaly.

Primitive mantle-normalized spider diagram (figure 9, primitive mantle data after Sun and McDonough 1989) indicates enrichment in Rb, Th, $\mathrm{La}, \mathrm{Sr}$ and $\mathrm{Ba}$ and depletion in $\mathrm{Ti}, \mathrm{Nb}, \mathrm{Zr}, \mathrm{Y}$, $\mathrm{Hf}, \mathrm{Sm}$ and $\mathrm{P}$. The LILE enrichment and $\mathrm{Nb}, \mathrm{Ti}$, $\mathrm{Zr}$ depletion suggest arc-like geochemical signature of the parent magma for the main gabbroic intrusive and the younger dolerite dykes. In the N-type MORB-normalized spider diagram (figure 10, Ntype MORB data after Sun and McDonough 1989), elements such as Rb, Ba, Th, K, La, Ce, Sr and

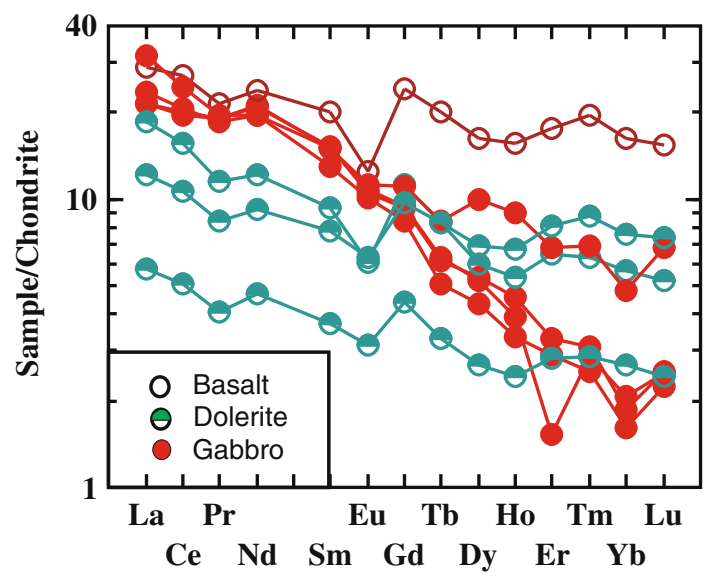

Figure 8. Chondrite normalized REE diagram (chondrite data after Sun and McDonough 1989) of intrusives of Paharpur.

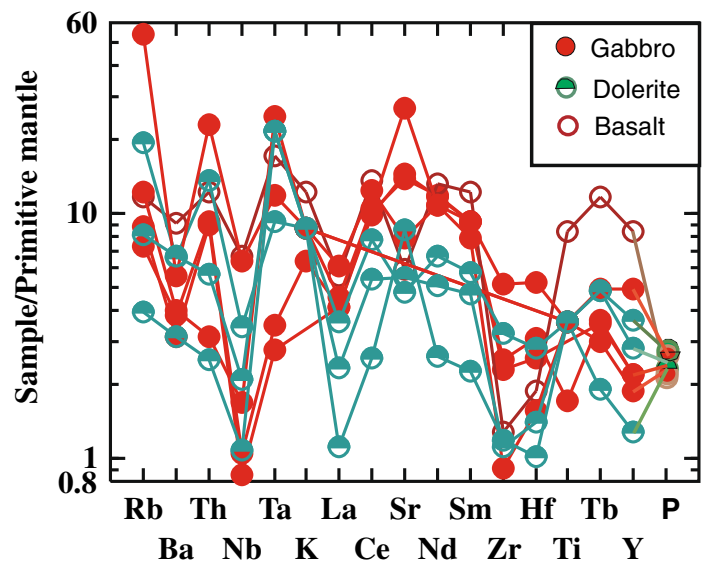

Figure 9. Primitive mantle normalized spider diagram (primitive mantle data after Sun and McDonough 1989) of intrusives of Paharpur. 


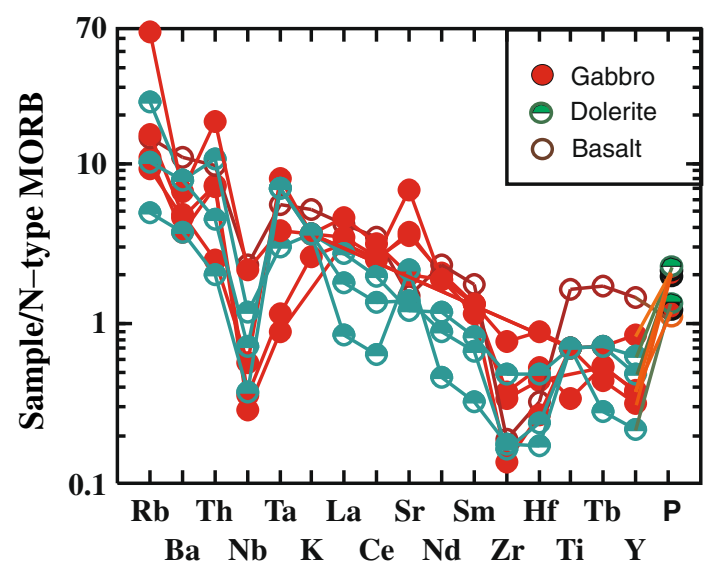

Figure 10. N-type MORB normalized spider diagram (Ntype MORB data after Sun and McDonough 1989) of intrusives of Paharpur.

Nd show variable amount of enrichment while elements such as $\mathrm{Nb}, \mathrm{Zr}$, Ti, Hf, Y, Tb and $\mathrm{P}$ show conspicuous depletion with respect to abundances of these elements in MORB.

\section{Petrogenesis}

Wide ranges of $\mathrm{SiO}_{2}(44.6-52.3 \%)$ and $\mathrm{mg}$ no. (27.3-69.7) in gabbroic intrusives of Paharpur is considered to be the result of magmatic differentiation. $\mathrm{K}_{2} \mathrm{O}$ shows positive correlation with $\mathrm{SiO}_{2}$ due to its incompatible nature. $\mathrm{MgO}, \mathrm{TiO}_{2}$ and $\mathrm{FeO}+\mathrm{Fe}_{2} \mathrm{O}_{3}$ show good linear negative correlation with $\mathrm{SiO}_{2}$ suggesting fractionation of early minerals such as olivine, pyroxenes, plagioclase, magnetite and ilmenite during differentiation. This is supported by clear positive correlation of $\mathrm{CaO}$, $\mathrm{Ni}, \mathrm{Sr}$ and negative correlation of total REE, $\mathrm{FeO}+\mathrm{Fe}_{2} \mathrm{O}_{3}$ and $\mathrm{TiO}_{2}$ with $\mathrm{mg}$ no. The negative $\mathrm{Eu}$ anomaly, observed in majority of the samples, suggest plagioclase fractionation as a dominant mode of differentiation. The anorthite content of some of the grains of plagioclase is high $\left(\mathrm{An}_{83-90}\right)$. It may indicate possibility of contamination or magma mixing. Paharpur intrusives show tholeiitic and iron enrichment trend in AFM diagram suggesting progressive iron enrichment during differentiation which suggests crystallization under low $\mathrm{fO}_{2}$ condition. Plots in TAS diagram suggest parent magma was of primitive in nature low abundances of $\mathrm{Ni}$ content suggest that the parent magma is not a primary one, but an evolved magma (olivine-fractionated).

Enrichment in LILE (Rb, Th, La and Sr) and depletion in elements of high ionic potential or High Field Strength Element (HFSE) like Nb, Zr, $\mathrm{Hf}, \mathrm{Sm}, \mathrm{Tb}, \mathrm{Ti}$ and $\mathrm{Y}$ is characteristic of the gabbroic and doleritic intrusives of Paharpur. These chemical characteristics are correlatable with the chemical compostion of hornblendebearing gabbroic rocks of ophiolitic suite and crosscutting dykes of tholeiitic to boninitic affinity in subduction zone setting. The enrichment in incompatible elements of low ionic potential or LILE (compared to MORB and primitive mantle) in the gabbroic and doleritic rocks of Paharpur is considered to have been derived from mantle source region which has been metasomatized by subducted sediment and subduction zone fluid. On the other hand, low abundance of elements of high ionic potential or HFSE might be the result of stability of minor residual phases (e.g., rutile, zircon and sphene) in the mantle source which preferentially concentrate a range of HFSE.

The $\mathrm{SiO}_{2}$ content of the magmatic rocks of Paharpur is comparable with IAT and average MORB, $\mathrm{MgO}$ with arc basalts and average Atlantic MORB, $\mathrm{Al}_{2} \mathrm{O}_{3}$ is lower than the average IAT and MORB, $\mathrm{CaO}$ corresponds with average Atlantic MORB and IAB. Within the minor oxides, $\mathrm{K}_{2} \mathrm{O}$ is comparable with average Atlantic MORB and IAT, $\mathrm{TiO}_{2}$ with island-arc basalts, $\mathrm{P}_{2} \mathrm{O}_{5}$ matches well with MORB and island-arc basalts. Among the trace elements, $\mathrm{Zr}, \mathrm{Y}$ and $\mathrm{Rb}$ match well with those of the IAT (elemental abundances of average MORB, IAT, island-arc basalt, average Atlantic MORB are taken from Wilson 1989). Enrichment and wide range of $\mathrm{Sr}, \mathrm{Rb}, \mathrm{La}$ and $\mathrm{Th}$ found in the magmatic rocks of Paharpur might be the result of metasomatism of mantle source by subducted sediment and subduction zone fluid. Low/ abundances of incompatible elements ( $\mathrm{Zr}, \mathrm{Y}, \mathrm{Nb}, \mathrm{Ti}$, Ta, etc.) may be attributed to either high degree partial melting of mantle source or stability of minor residual phases (zircon, rutile and sphene) in the mantle source which preferentially concentrate these trace elements. Although a few incompatible elements have restricted range, most of them show highly variable abundances, ranging from much higher to lower than those of island-arc basalts which possibly indicates the process other than mineral accumulation (migration of interstitial melt and aqueous fluid) have contributed bulk compositional variations among the intrusives as observed from hornblende-bearing gabbro from Volcan San Pedro of Chilean Andes (Costa et al 2002).

Rare earth element composition of the rocks when plotted in the $\mathrm{Lu} / \mathrm{Hf}$ vs. La/Sm diagram (figure 11, after Regelous et al 2003) lie in the fields of spinel peridotite and garnet peridotite and indicate $5 \%$ to $20 \%$ partial melting of the mantle source. Similar observations have been made on the mafic intrusives of Sichuan Province, China where the source was considered as garnet-spinel lherzolite (Zhao and Fu 2007). The temperature 


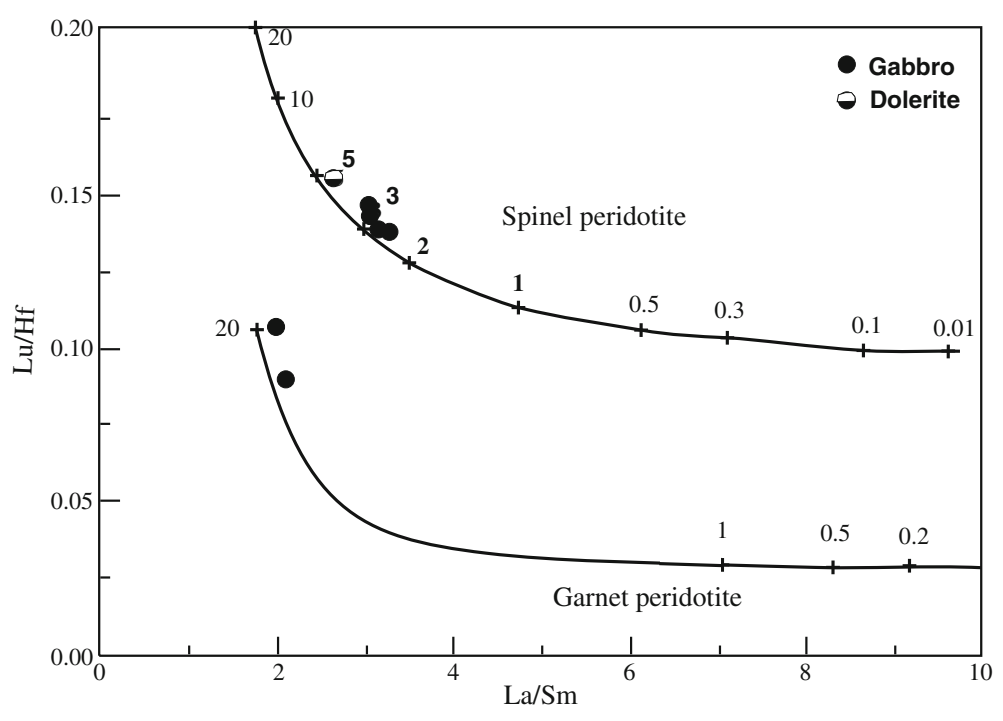

Figure 11. Lu/Hf vs. La/Sm plot for mafic intrusives of Paharpur, after Regelous et al (2003).

for the crystallization of the mother magma for the gabbroic intrusive of Paharpur is estimated from coexisting orthopyroxene-clinopyroxene pair to be $805^{\circ}-1077^{\circ} \mathrm{C}$ using two pyroxene thermometer (after Kretz 1992). The pressure range over which the parent magma had crystallized is estimated from coexisting plagioclase-clinopyroxene pair to be around 5.9 to 7.9 kbar using clinopyroxeneplagioclase barometer (after McCarthy and Douce 1998). The estimated range of pressure and temperature for the crystallization of parent magma of Paharpur gabbroic rock is indicative of polybaric crystallization over the entire crustal column and corresponds well with mafic intrusions from the Cascadian Arc System (Ulmer 2007) and Mexican province of South America (Guttirez et al 2008) and the $\mathrm{P}-\mathrm{T}$ condition corroborates well with spinel peridotite as the mantle source rock for the mother magma. The pressure range (5.9-7.9 kbar) is consistent with deep level (crust-mantle boundary) and intermediate crustal level $(15-25 \mathrm{~km})$ magma storage areas where fractionation-induced differentiation takes place. Lesser abundance of HREE and flat HREE pattern in chondrite normalized diagram possibly suggest stability of garnet in the residual phase during mantle melting.

In summary, it is considered that the mantle source region beneath Paharpur is considered to have metasomatized by subducted sediment and subduction zone fluid leading to enrichment in LILE (Rb, Th, K, La and Sr) and relative depletion in HFSE (Nb, Ti, Zr, Y and Tb) prior to melting. Partial melting (5-20\%) of such an enriched mantle source gave rise to the parent magma for the magmatic rocks of Paharpur. Magmatic crystallization and differentiation continued in the deep to intermediate level crustal magma over a temperature range of $805^{\circ}-1077^{\circ} \mathrm{C}$ and pressure range of 5.9-7.9 kbar. Fractional crystallization of early formed olivine, orthopyroxene, clinopyroxene, plagioclase and ilmenite has been considered as main process of differentiation accompanied by the reaction of early cumulate pile with extraneous aqueous fluid/evolved melt. Large poikilitic hornblende, which is a dominant mineral phase and encloses all the early minerals, is considered as product of such fluid/evolved melt-induced reaction during late magmatic stage.

\section{Tectonic setting}

Each specific tectonic setting is more or less typified by geochemical characteristics of associated volcanic products. It is possible therefore that such geochemical characterization of basaltic rocks can be used to recognize unknown tectonic setting. However, the major element chemistry is not so useful in tectonic discrimination. On the other hand, immobile, incompatible minor and trace elements are very useful in tectonic discrimination as they have restricted range for individual tectonic setting (Rollinson 1993). Abundances of trace elements (Nb, Zr, Ti, P, Cr, Y, Mn, Sr and Ce) are used to understand the unknown tectonic setting of magmatic rocks of Paharpur using some tectonic discrimination diagrams.

In the $2 \mathrm{Nb}-\mathrm{Zr} / 4-\mathrm{Y}$ diagram (figure 12, after Meschede 1986), most (7 out of 9) of the samples are plotted within field $\mathrm{D}$, which is the field for N-type MORB or volcanic-arc basalts (VAB).

Similar observation can be obtained from $\mathrm{MnO}-$ $\mathrm{TiO}_{2}-\mathrm{P}_{2} \mathrm{O}_{5}$ diagram (after Mullen 1983). 


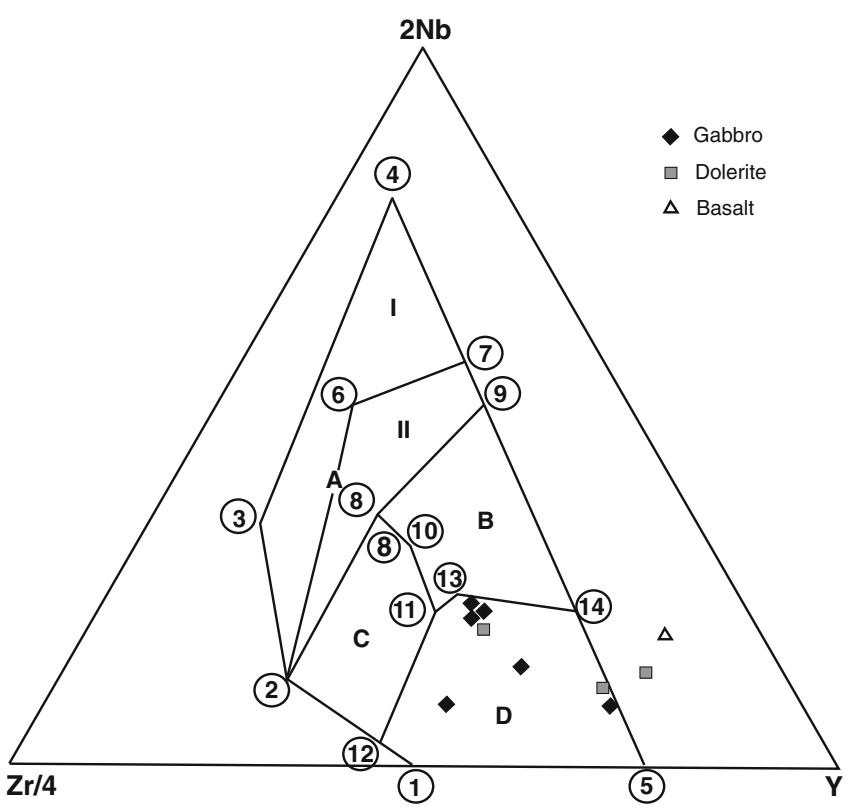

Figure 12. 2Nb-Zr/4-Y diagram of the mafic intrusives of Paharpur, after Meschede (1986). Black-filled squares represent the mafic intrusive compositions. Field AI: within-plate alkali basalt; AII: within-plate alkali basalt and within-plate tholeiite; B: E-type MORB; C: within-plate tholeiite and volcanic arc basalts; D: N-type MORB and volcanic arc basalts.

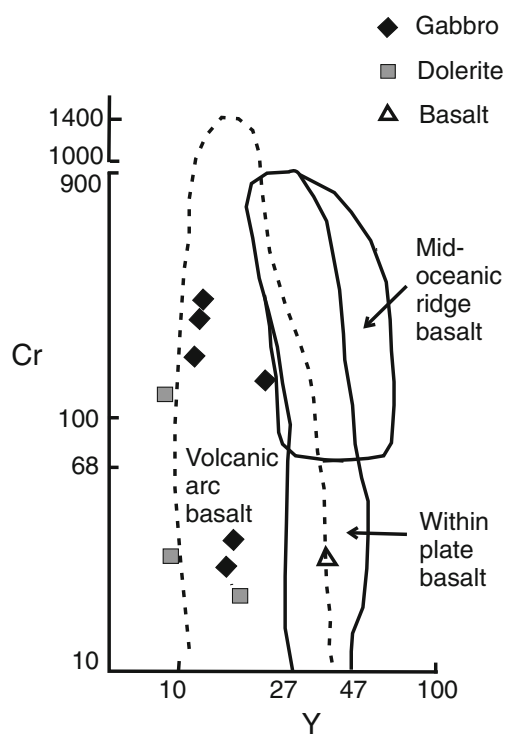

Figure 13. Cr-Y diagram for mafic intrusives of Paharpur, after Pearce (1982).

In the $\mathrm{Cr}-\mathrm{Y}$ diagram (figure 13, after Pearce 1982), most (7 out of 9 ) of the intrusives plot within the field of VAB.

Similar nature of the intrusives is observed in the Cr-Ce/Sr diagram (after Pearce 1982).

$\mathrm{Ti}-\mathrm{Al}$ plot of the clinopyroxenes (figure 14, after Leterrier et al 1982) suggest tholeiitic nature of the mafic intrusives of Paharpur.

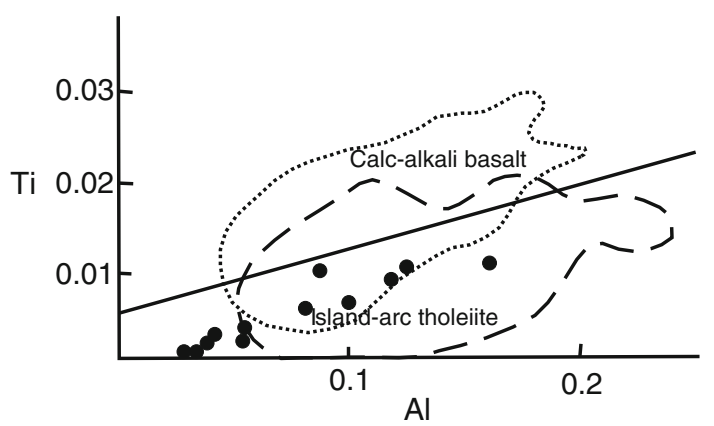

Figure 14. Ti-Al plot of clinopyroxene of the mafic intrusives of Paharpur, after Leterrier et al (1982). Black-filled circles represent clinopyroxene compositions.

Petrological and geochemical data give evidence that the gabbroic rocks and associated dolerite dykes of Paharpur was formed in a subduction zone setting.

\section{Discussion}

Subduction zone is considered as the most complex area of magma generation. This is because of involvement of multiple source materials namely subducted oceanic crust, overriding mantle wedge, subducted sediments and subduction zone fluid in melting episode and magma generation process (Wilson 1989). The magmatic rocks of ophiolitic assemblage in a subduction zone clearly display a strong IAT and boninitic character (Winter 2001). Fluid phases usually play an important role in the magmatic process of subduction zone; as a result hydrous minerals (hornblende \pm phlogopite) are very common in the intrusives. Hornblende in the gabbroic rocks of subduction zone occurs either as early formed smaller crystals as seen in Adamello batholith, Italy (Ulmer et al 1983); hornblende gabbro sill, California (Sisson et al 1996) or as poikilitic crystals enclosing earlier-formed minerals showing reaction relation as observed in peninsular ranges batholith, California (Smith et al 1983); coastal batholith of Peru (Regan 1985); hornblende gabbro from Chilean Andes (Costa et al 2002) and Evros ophiolites from NE Greece (Bonev and Stampfli 2009).

The high modal proportion of poikilitic hornblende (up to 60\%) in the gabbroic intrusives of Paharpur is very significant. The $\mathrm{mg}$ no. of these hornblendes is also very high. Such high values may indicate primitive characters, and possibly suggest that large proportion of hornblende are produced by reactions between early crystallized minerals (clinopyroxene orthopyroxene and plagioclase) and evolved melt \pm aqueous fluids that percolate through the mafic cumulate triggered by protracted closed system crystallization during 
late magmatic stage. Interactions between mafic cumulate piles and invading water-rich silicic magmas may provide a means for stabilizing substantially larger quantities (nearly 62 volume\%) of hornblende.

The dolerite dykes, which intrude the main gabbroic rock of Paharpur, show largely tholeiitic character with one sample showing high $\mathrm{Mg}-\mathrm{Si}$ and low Ti abundance and appear to show a boninitic affinity. Arc tholeiites and boninites are known from the fore arcs of the modern arc/back arc environment and points to the early stages of arc system evolution (Taylor 1995). The magmatic assemblage showing tholeiitic and boninitic affinities is observed in ancient arc systems and ophiolite suites.

Geochemical studies on the mafic intrusive rocks of Paharpur indicate an HFSE-depleted and LILEenriched signature with conspicuous negative $\mathrm{Nb}$, $\mathrm{Ti}$ and $\mathrm{Zr}$ anomaly which is considered characteristic of basaltic rocks of subduction zone (Wilson 1989; Bektas et al 2007). High values of $\mathrm{Cr}$ (18-670 ppm), Ni (14-234 ppm), La/Nb (2.5$12.6)$ and $\mathrm{Zr} / \mathrm{Nb}(2.6-37.4)$ ratio, rule out the possibility of crustal contamination (average crust has $\mathrm{La} / \mathrm{Nb}=2.2, \mathrm{Zr} / \mathrm{Nb}=16.2$, after Weaver 1991). Ba/Nb ratio is also very high in this rock compared to the crust. In subduction zone, fluid phase and subducted sediment are two chief source materials which contribute significantly in magmas and impart characteristic geochemical signature (Guram et al 2007; Shigenori and Kazuaki 2007). In the present case, the subduction zone fluid which is enriched in LILE (Rb, Sr) is considered to have played a dominant role in metasomatism of the mantle source along with the sediment which is rich in Th and LREE. Tectonic discrimination diagrams using chemical attributes suggest a calc-alkaline affinity for the mafic intrusives (gabbro and associated dolerite dykes) of the study area and a possible arc-setting. On the basis of the field occurrence, mineralogy, major and trace element behaviour of the mafic intrusives of the study area, it appears that the intrusive bodies have some characters similar to gabbroic and doleritic rocks of subduction zones. Similar observations were made from mafic rocks of Chilean Andes (Costa et al 2002); Duke Island, southeastern Alaska (Himmelberg and Loney 1994), northeastern Turkey (Bektas et al 2007); Sichuan province, southwestern China (Zhao and Fu 2007); Evros ophiolite, NE Greece (Bonev and Stampfli 2009) and many other places. Profuse occurrence of poikilitic hornblende in gabbro bodies suggest activity of hydrous fluid during late magmatic stage which is characteristic of basic rocks of ophiolites in subduction zone. The mafic-ultramafic rocks along NPSZ, located along $\mathrm{E}-\mathrm{W}$ zone about $25 \mathrm{~km}$ north of the present study area have also been reported to show subduction zone geochemical signature (Mandal and Ray 2009). The orientation of fossil intra-plate subduction zone is likely to be E-W and a possible northward subduction of the southern block might have resulted in formation of mafic rocks of Paharpur area with subduction zone component.

\section{Conclusion}

Field and laboratory observations on gabbroic rocks and associated dolerite dykes of the study area suggest that these rocks were formed and emplaced in subduction zone setting. The field occurrence, rock-types, mineralogy, texture and geochemistry of these rocks have striking similarities with gabbroic rocks of subduction zone and with basic rocks of ophiolite complex developed in supra subduction zone of arc-marginal basin setting. Paharpur intrusive is characterized by its more basic, hydrous and evolved nature. Processes other than mineral accumulation such as, migration of interstitial melt and aqueous fluid may contribute bulk compositional variation among the intrusives indicated by abundances of trace elements. The variation in major elements and ratios of trace elements suggest variable crustal contamination in mantle source prior to melting.

\section{Acknowledgements}

Authors would like to thank the Head of the Department of Geology, Presidency University for using laboratory facility and DST-FIST for infrastructural support. They also thank Dr Basab Chattopadhyay, Senior Geologist, Geological Survey of India for EPMA in the Chemical Laboratory of GSI, Kolkata; Mr P Mondal, Director, Chemical Division, Geological Survey of India, Kolkata for major, trace and rare earth element analyses and Dr V Balaram, Head, Geochemistry, National Geophysical Research Institute for the same. Thanks are also due to the Department of Science and Technology, Govt. of India, New Delhi for providing financial support for field work chemical analyses.

\section{References}

Arculus R J and Wills K J A 1980 The petrology of plutonic blocks and inclusions from the Lesser Antilles island arc; J. Petrol. 21 743-799.

Baidya T K, Chakravarty P S, Drubetskoy E and Khiltova V J 1987a New geochronological data on some granitic phases of the Chhotanagpur granite gneiss complex in the northwestern Purulia district, West Bengal; Indian J. Earth Sci. 14(2) 136-141. 
Baidya T K, Maity N and Biswas P 1987b Tectonic phases and crustal evolution in a part of the Eastern Chhotanagpur Gneissic Complex; J. Geol. Soc. India 34(3) 318-324.

Beard J S 1986 Characteristic mineralogy of arc-related cumulate gabbros: Implications for the tectonic setting of gabbroic plutons and for andesite genesis; Geol. Soc. Am. 14 848-851.

Beard J S and Borgia A 1989 Temporal variation of mineralogy and petrology in cognate gabbroic enclaves at Arenal volcano, Costa Rica; Contrib. Mineral. Petrol. 103 110-122.

Beccaluva L, Bianchini G, Bonadiman C, Siena F and Vaccaro C 2004 Coexisting anorogenic and subductionrelated metasomatism in mantle xenoliths from the Betic Cordillera (southern Spain); Lithos 75 67-87.

Bektas O, Eyoboglu Y, Sen C and Rojay B 2007 Reverlely zoned Alaskan-type mafic-ultramafic cumulates in the eastern Pontide magmatic arc, NE Turkey; Geophys. Res. Abstr. 9 01036p.

Biggazzi G A, Del Moro F, Innocenti K, Kyriakopoulos P, Manetti P, Papadopoulos P, Norilliri A and Magganas 1989 The magmatic intrusive complex of Petrota, West Thrace: Age and geodynamic significance; Geol. Rhodopica 1 290-297.

Bonev N and Stampfli G 2005 Compositional diversity of the Evros ophiolite, Thrace, northeastern Greece: Field occurrences, preliminary petrologic and geochemical data on plutonic sequence and tectonic implications; Proceedings of Annual Conference of Bulgarian Geological Society, 17-18 November 2005, Sofia, Bulgaria, pp. 28-31.

Bonev N and Stampfli G 2008 Petrology, geochemistry and geodynamic implications of Jurassic island arc magmatism as revealed by mafic volcanic rocks in the Mesozoic low-grade sequence, eastern Rhodope, Bulgaria; Lithos $100210-233$.

Bonev N and Stampfli G 2009 Gabbro, plagiogranite and associated dykes in the supra-subduction zone Evros Ophiolites, NE Greece; Geol. Mag. 146(1) 72-91.

Bose M K 1997 Igneous petrology (Calcutta: World Press), $358 \mathrm{p}$.

Boudreau A E 1999 Fluid fluxing of cumulates: The JM Reef and associated rocks of the Stillwater Complex, Montana; J. Petrol. 40 755-772.

Brown G C 1982 Calc-alkaline intrusive rocks: Their diversity, evolution and relation to volcanic arcs; In: Andesites: Orogenic andesites and related rocks (ed.) Thorpe R S, John Willey, pp. 437-461.

Conrad W K and Kay R W 1984 Ultramafic and mafic inclusions from Adak island: Crystallization history, and implications for the nature of primary magmas and crustal evolution in the Aleutian arc; J. Petrol. 25 88-125.

Costa F, Dungan M A and Singer B S 2002 Hornblende- and Phlogopite-bearing gabbroic xenoliths from Volcán San Pedro $\left(36^{\circ} \mathrm{S}\right)$, Chilean Andes: Evidence for melt and fluid migration and reactions in subduction-related Plutons; J. Petrol. 43(2) 219-241.

De Bari S M 1994 Petrogenesis of the Fiambalá gabbroic intrusion, northwestern Argentina, a deep syntectonic pluton in a continental magmatic arc; J. Petrol. 35 679-713.

Frass A, Hegewald S, Closs R M, Tesch C and Arikas K 1990 The geology of the graben of Petrota (Thrace, NE Greece); Geologica Rhodopica 2 50-63.

Ghosh N C 1983 Geology, tectonic evolution of the Chhotanagpur granite gneiss complex, eastern India; (ed.) Sinha Roy S, Recent Res. Geol. 10 211-247.

Ghosh N C and Chatterjee N 2008 Petrology, tectonic setting and source of dykes and related magmatic bodies in the Chhotanagpur Gneissic Complex, eastern India;
In: Indian Dykes (eds) Srivastava RK, Shivaji $\mathrm{CH}$ and Chalipati Rao N V (New Delhi: Narosa Publishing House), pp. 671-693.

Guram S Z, Yildirim D, Adamia S A, Oberhansli R E and Karpenko S F 2007 Geochemistry and geochronology of the Neoproterozoic Pan-African transcaucasian Massif (Republic of Georgia) and implications for island arc evolution of the late Precambrian Arabian-Nubian Shield; Gondwana Res. 11 92-108.

Guttirez FO, Elias-Herrera M and Davalos-Elizondo G 2008 On the nature and role of the lower crust in the volcanic front of the Trans-Mexican Volcanic Belt and its fore-arc region, southern and central Mexico; Rev. Mex. Cienc. Geol. 25(2) México ago.

Hebert R and Laurent R 1990 The mineralogical study of a cross-section through the plutonic part of the Troodos ophiolite: New constraints for genesis of arctype ophiolite; In: Ophiolites-Oceanic crustal analogues (eds) Malpas J et al, Proceedings of the Symposium 'Troodos 1987': Nicosia, Cyprus Geological Survey, pp. 149-164.

Heliker C 1995 Inclusions in Mount St. Helens dacite erupted from 1980 through 1983; J. Volcanol. Geotherm. Res. 66 115-135.

Hickey-Vargas R, Abdollahi M J, Parada M A, LopezEscobar and Frey F A 1995 Crustal xenoliths from Calbuco volcano, Andean southern volcanic zone: Implications for crustal composition and magma-crust interaction; Contrib. Mineral. Petrol. 119 331-344.

Himmelberg G R and Loney R A 1994 Petrogenesis of gabbronorite at Yakobi and northwest Chicago islands, Alaska; Geol. Soc. Am. Bull. 98 265-279.

Irvine TN 1980 Magmatic infiltration metasomatism, double diffusive fractional crystallisation, and adcumulous growth in the Muscox intrusion and other layered intrusions; In: Physics of Magmatic Processes (ed.) Hargraves R B (NJ: Prinston University Press), pp. 325-383.

Kretz R 1992 Transfer and exchange equilibria in a portion of the pyroxene quadrilateral as deduced from natural and experimental data; Geochim Cosmochim Acta $\mathbf{4 6}$ 411-421.

LeBas M J and Streckeisen A L 1991 The IUGS systematics of igneous rocks; J. Geol. Soc. London 148 825-833.

Leterrier J, Mnury R C, Thonon P, Girard D and Marchal M 1982 Clinopyroxene composition as a method of identification of the magmatic affinities of the paleo-volcanic series; Earth Planet. Sci. Lett. 59 139-154.

Magganas A C 2002 Constraints on the petrogenesis of Evros ophiolite extrusives, NE Greece, Lithos 65 165-182.

Magganas A C 2007 Plagiogranitic rocks of Evros ophiolite, NE Greece; Bull. Geol. Soc. Greece 40 884-898.

Magganas A C, Sideris C and Kokkinakis A 1991 Marginal basin-volcanic arc origin of metabasic rocks of the Circum-Rhodope Belt, Thrace, Greece; Mineral. Petrol. $44235-252$.

Mandal A and Ray A 2009 Petrology of Mafic-Ultramafic rocks along North Puruliya Shear Zone, West Bengal; J. Geol. Soc. India 74 108-118.

Mandal A, Goswami B, Mukherjee S, Das S, Bhattacharyya I and Bhattacharyya C 2007 Mantle metasomatism of ultramafic intrusives in Chhotanagpur Granite Gneiss Complex, Puruliya District, West Bengal, eastern India: Evidence from trace element and REE geochemistry; In: Igneous Petrology: 21st Century Perspective (eds) Ray J S and Bhattacharyya C, Allied Publishers Pvt. Ltd., pp. $122-142$.

Mazumder S K 1988 Crustal evolution of Chhotanagpur gneissic complex and the Mica Belt of Bihar; In: Precambrian of the Eastern Indian Shield (ed.) Mukhopadhaya D, Geol. Soc. India Memoir 8 49-83. 
McBirney A R 1995 Mechanisms of differentiation in the Skaergaard Intrusion; J. Geol. Soc. London 152 421-435.

McCarthy T C and Patino Douce A E 1998 Empirical calibration of the silica-Ca-Tschermak's-anorthite (SCAn) geobarometer; J. Met. Geol. 16 675-686.

Meschede M 1986 A method of discriminating between different types of mid-ocean ridge basalts and continental tholeiites with the Nb-Zr-Y diagram; Chem. Geol. 56 207-218.

Mullen E D $1983 \mathrm{MnO} / \mathrm{TiO}_{2} / \mathrm{P}_{2} \mathrm{O}_{5}$ : A major element discriminant for basaltic rocks of oceanic environments and its implication for petrogenesis; Earth Planet. Sci. Lett. $6253-62$.

Pearce J A 1982 Trace element characteristics of lavas from destructive plate boundaries; In: Andesites (ed.) Thorpe R S (Chichester: Wiley), pp. 525-548.

Prouteau G, Scaillet B, Pichavant M and Maury R 2001 Evidence for mantle metasomatism by hydrous silicic melts derived from subducted oceanic crust; Nature $\mathbf{4 1 0}$ 197-200.

Ray Barman T, Bishui P K, Mukhopadhyay K and Ray J N $1994 \mathrm{Rb}-\mathrm{Sr}$ geochronology of the high grade rocks from Purulia, West Bengal and Jamua-Dumka sector, Bihar; Ind. Mins. 48(1-2) 45-60.

Regan P F 1985 The early basic intrusions; In: Magmatism at a plate edge (eds) Picher W S, Autherton M P, Kobbing E J and Beckinsale R D (London, Blackie), pp. 72-89.

Regelous M, Hofmann A W, Abouchami W and Galer S J G 2003 Geochemistry of lavas from the Emperor Seamounts, and the geochemical evolution of Hawaiian magmatism from 85 to $42 \mathrm{Ma}$; J. Petrol. 44 113-140.

Rollinson H R 1993 Using geochemical data: Evaluatuon, presentation, interpretation, Longmans Harlow, 695 Third Avenue, New York, NY 10158.

Roy A, Sarkar A, Jeyakumar S, Aggrawal S K and Ebihara M 2002 Sm-Nd age and mantle source characteristics of the Dhanjori volcanic rocks; Geochem. J. 36 503-518.

Sarkar A N 1988 Tectonic evolution of the Chhotanagpur plateau and Gondwana basins in eastern India: An interpretation based on supra-subduction geological processes; In: Precambrian of the Eastern Indian Shield, (ed.) Mukhopadhyay D, Geol. Soc. India Memoir 8 127-146.

Sengupta D K and Sarkar S N 1964 Structure of the granitic rock and associated metamorphites of the area around Muri-Silli-Jhalida, Ranchi and Purulia Districts, India; 22nd International Geological Congress 4 374-389.
Shigenori M and Kazuaki O 2007 Water transportation from the subducting slab into the mantle transition zone; Gondwana Res. 11 148-165.

Sisson T W, Grove T L and Koleman D S 1996 Hornblende gabbro sill complex at Onion Valley, California, and a mixing origin for the Sierra Nevada batholith; Contrib. Mineral. Petrol. 126 81-108.

Smith T E, Huang C H, Walawender M J, Cheung P and Wheeler C 1983 The gabbroic rocks of the peninsular ranges, southern California: Cumulate rocks associated with calc-alkaline basalts and andesites; J. Volcan. Geotherm. Res. 18 249-278.

Streckeisen A L 1973 Classification and nomenclature recommended by the IUGS subcommission on the systamatics of igneous rocks; Geotimes 18(10) 26-30.

Sun S-S and McDonough W F 1989 Chemical and isotopic systematics of oceanic basalts: Implication for mantle composition and processes; In: Magmatism in the ocean basins (eds) A D Saunders and M J Norry, Blackwell Sci. Publ. 42 313-345.

Taylor B 1995 Backarc basins: Tectonics and magmatism (Plenum Press: New York), 524p.

Ulmer P 2007 Differentiation of mantle-derived calc-alkaline magmas at mid to lower crustal levels: Experimental and petrologic constraints; Periodico di Mineralogia 76(2-3) 309-325.

Ulmer P, Callegari E and Sonderegger U C 1983 Genesis of the mafic and ultramafic rocks and their genetical relations to the tonalite-trondhjemitic granitoids of the southern part of Adamello batholith (Norway Italy); Mem. Della. Societa. Geologica. Italiana. 26 171-222.

Weaver B L 1991 The origin of ocean island basalt endmember compositions: Trace element and isotopic constraints; Earth. Planet. Sci. Lett. 104 381-397.

Wilson M 1989 Igneous Petrogenesis, Chapman and Hall, London.

Winter J D 2001 An introduction to Igneous and Metamorphic Petrology, Prentice Hall, 687p.

Yagi K and Takeshita H 1987 Impact of hornblende crystallization for the genesis of calc-alkaline andesites; In: Magmatic Processes: Physicochemical principles (ed.) Mysen B O, The Geochem. Soc. Spec. Publ. 1 183-190.

Zhao J H and Fu M 2007 Geochemistry of Neoproterozoic mafic intrusions in the Panzhihua district (Sichuan Province, SW China): Implications for subduction-related metasomatism in the upper mantle; Precamb. Res. 152(1-2) 27-47. 